\section{Lower Cretaceous reservoir development in the North Sea Central Graben and potential analogue settings in the Southern Permian Basin and South Viking Graben}

Frank Zwaan ${ }^{1,2 *}$

${ }^{1}$ Project work: VU University Amsterdam, Faculty of Earth and Life Sciences, De Boelelaan 1085-1087, 1081 HV Amsterdam, ${ }^{2}$ Currently: University of Bern, Institute of Geological Sciences, Baltzerstrasse 1+3, CH-3012 Bern, Switzerland)

*Corresponding author:frank.zwaan@geo.unibe.ch

\begin{abstract}
Much of the future hydrocarbon exploration potential in the North Sea lies in locating stratigraphic traps and discrete reservoir intervals. This study assesses the potential for Lower Cretaceous reservoirs, with particular focus on the Norwegian Central Graben and proposed methods to identify future prospects over a wider area. Seismic interpretation and well data reveal the structure and sedimentology of the study area. Although the region was isolated from a large hinterland in the Early Cretaceous, potential local sediment sources, sediment transport routes and areas with possible reservoir development are identified. The greater Mandal High area, where Lower Cretaceous shoreface deposits and submarine fan systems are postulated, is suggested for primary focus. Similar deposits may have developed around the other exposed highs in the region, although several were drowned towards the end of the Early Cretaceous. Detailed seismic and stratigraphic analysis will be necessary to identify individual reservoir units. Since similar settings may have occurred in the adjacent South Viking Graben and Southern Permian Basin regions during the Early Cretaceous, further reservoir assessment is recommended for the North Sea in general.
\end{abstract}

KEYWORDS: Lower Cretaceous, Tectonics, Reservoir prediction, Hydrocarbon exploration

Abstract Word Count: 180

Main Body Word Count (excluding abstract, figure captions \& references): 7723

References Word Count: 3999, including DOIs

Figure Caption Word Count: 1400 Words (incl table caption), 11 figures, 1 table

THIS IS A POSTPRINT VERSION, FINAL VERSION PUBLISHED IN: KILHAMS, B., KUKLA, P. A., MAZUR, S., MCKIE, T., MIJNLIEFF, H. F. \& VAN OJIK, K. (eds) Mesozoic Resource Potential in the Southern Permian Basin. Geological Society, London, Special Publications, 469, https://doi.org/10.1144/SP469.3 @ 2018 
The Central Graben of the North Sea represents a prolific and mature hydrocarbon province (e.g. Brooks 1990). Despite 50 years of exploration, further potential continues to be unlocked as demonstrated by the Upper Jurassic shoreface play (e.g. Edvard Grieg and Johan Sverdrup discoveries at the Norwegian Utsira High, Jørstad 2012; NPD 2017; Lundin 2017) and by the Upper Jurassic turbidite play in the United Kingdom (UK) Moray Firth (e.g. Buzzard field, Fraser et al. 2003; Ray et al. 2010). This paper describes further potential in another stratigraphic horizon, namely the Lower Cretaceous reservoirs of the North Sea. Here shoreface and deep water reservoir units are developed associated with discrete Mesozoic rifting phases and related localised depocenters.

Lower Cretaceous deep marine sandstones represent an important play in the UK Moray Firth (e.g. Garrett et al. 2000; Johnson et al. 2005, Figs. 1a, 2), where large amounts of sand from the exposed East Orkney High and Halibut Horst were shed into adjacent basins of the Innerand Outer Moray Firth, forming the reservoirs for various hydrocarbon fields (e.g. Scapa, Britannia, McGann et al. 1991; Ainsworth et al. 2000). Various studies have established sediment transport directions (Hailwood \& Ding 2000), sediment provenance areas (Blackbourn \& Thomson 2000) and a sequence stratigraphic framework (Jeremiah 2000) in this area.

In contrast to the Moray Firth, the Lower Cretaceous play remains underdeveloped in the Central Graben (Copestake et al. 2003; NPD 2017). While the generalised Mesozoic sequence is visible on seismic in the Moray Firth, the thick (2000 to $4500 \mathrm{~m}$ ) Cenozoic and Upper Cretaceous overburden in the Central Graben presents an issue for seismically driven reservoir identification within the Lower Cretaceous (up to $30 \mathrm{~m}$ net reservoir thickness) (Argent et al. 2000; Law et al. 2000). Further factors impeding seismic assessment include multiples (induced by the base of the overlying Upper Cretaceous chalk units) and the general low impedance contrast between sandstones and shales in this interval (Oakman 2005). Although seismic imaging quality has improved considerably in recent years (e.g. Hampson et al. 2010), alternative methods are required to assess the Lower Cretaceous units and to locate potential prospects. Attempts to delineate reservoir development have been made in the UK Central Graben (UKCG) with the use of regional 3D seismic and well data (Milton-Worssell et al. 2006, Fig. 1a), indicating significant potential for Lower Cretaceous sandstone development. Currently, other than local studies (e.g. Rossland et al. 2013), no published work has established a similar overview of Lower Cretaceous reservoir potential in the Norwegian sector of the Central Graben.

This study, therefore, aims to assess the potential for Lower Cretaceous sand bodies in the Norwegian Central Graben (NCG) and to link this interpretation to adjacent areas in the UK and to the Danish, German and Dutch parts of the North Sea Rift System (Southern Permian Basin area), as well as to the South Viking Graben (Fig. 1a). 
The geological history of the Central North Sea has generated a diverse stratigraphic record, which is hereby described utilising a Norwegian stratigraphic nomenclature (Isaksen \& Tonstad 1989; NPD 2017, Fig. 2). The oldest known units in the Norwegian Central Graben are of pre-Permian age; Silurian to Devonian metamorphic basement overlain by Old Red sandstones (Fossen et al. 2008). These units are followed, in stratigraphic order, by varied Carboniferous deposits (NPD 2014), Lower Permian Rotliegend sandstones and thick Upper Permian Zechstein evaporites plus dolomites. The halite sequences of the Zechstein have had a profound influence on the tectonic style; decoupling underlying and overlying strata (Hodgson et al. 1992; Stewart 2007; Ge et al. 2016; Jackson \& Lewis 2016; Van Winden this volume). Lower Triassic Smith Bank Shales and Middle to Upper Triassic Skagerrak Sandstone deposition coincided with Late Triassic faulting along the inherited Caledonian structural grain (Bartholomew et al. 1993; UKDD 2007). This first rifting phase formed the general Central Graben structure, as these Triassic faults were partially reactivated in the Late Jurassic and Early Cretaceous (Rattey \& Hayward 1993), although the main Triassic and Jurassic to Early Cretaceous depocenters do not precisely coincide (Erratt et al. 1999). Uplift and erosion due to an Early Jurassic mantle plume formed the Mid-Cimmerian unconformity in the Central North Sea (Underhill \& Partington 1993). Middle Jurassic Bryne Formation coastal plain deposits succeed the hiatus (Bergan et al. 1989), followed by a second erosional surface. Eventual dome collapse coincided with the onset of renewed extension in the Northern North Sea (Graversen 2006), propagating into the Central North Sea during Late Jurassic times (Rattey \& Hayward 1993). As rifting proceeded, sediment-starved deep marine basins developed (Copestake et al. 2003). This transgression is recorded in the syn-rift Jurassic Tyne Group by the Ula Formation shoreface sandstones and subsequent deep marine shales, including Mandal Formation source rock (Gautier 2005; Nøttvedt \& Johannessen 2008).

Major extension ceased towards the end of the Kimmeridgian (Milton 1993), although a secondary phase of rift activity may have continued into the Earliest Cretaceous or Ryazanian in the Norwegian area, especially in the NCG (Gowers et al. 1993; Sears et al. 1993; Zanella et al. 2003; Ge et al. 2016). Rifting ceased as extensional stresses shifted to the proto-North Atlantic (Coward et al. 2003, Oakman 2005). Subsequently, post-rift thermal sag initiated and sediments began to cover the rift topography above the Base Cretaceous Unconformity (BCU) (Rattey \& Hayward 1993). The first of these, the Cromer Knoll Group, contains mostly shales but also marly limestones (Tuxen Formation) plus shoreface to deep marine sandstones (Ran Sandstone units, Isaksen \& Tonstad 1989). The sandstones represent potential reservoir bodies but their spatial and temporal extent is poorly constrained, being encountered in only a few wells. In the Aptian, another shift in tectonics and oceanography, the "Austrian event", occurred. This coincided with the onset of alpine compression and the opening of the North Atlantic, leading to more restricted basins and to the deposition of dark muds of the Sola Formation, overlain by calcareous Rødby Formation sediments (Garrett et al. 2000; Copestake et al. 2003). 
115 Global sea level rise and a shift to a tropical climate in the Late Cretaceous saw the 116 development of massive Upper Cretaceous chalk units in the North Sea sag basin (Surlyk et al. 2003). Thermal subsidence was, however, interrupted by local inversion pulses and associated Zechstein salt diapirism (Cartwright 1989; Johnson et al. 2005; Van Winden this volume). Renewed sediment input from the eroding North Atlantic rift shoulders gave rise to widespread turbidite systems in the Paleocene and Eocene. From the Oligocene onwards, thermal sag continued, concentrated in the NW of the NCG (Gowers \& Sæbøe 1985), while the North Sea basin gradually filled in with thick clastic sequences.

\section{ESTABLISHED LOWER CRETACEOUS UK RESERVOIRS}

124

125

126

127

128

129

130

131

132

133

134

135

136

137

138

139

140

141

142

143

144

145

146

147

Three major sequences of sandstone deposits occur in the Inner Moray Firth (Copestake et al. 2003, Fig. 2); Ryazanian-Valanginian Punt sandstones SW of the Halibut Horst, Wick Sandstones south of the East Orkney High and Scapa Sandstones east of the Halibut High (locations in Fig. 1). In Barremian times, Coracle Sandstones of the Wick Fm occurred south of the East Orkney High and the Halibut High, whilst Scapa Sandstones were still present in the Witch Ground Graben (Jeremiah 2000). These units of the Lowermost Cretaceous (Ryazanian-Barremian play) were deposited during a phase of low sea level due to tectonic activity related to Austrian compression, ending with a major flooding event in the Barremian (Crittenden et al. 1997; Oakman 2005). Rejuvenated tectonic activity associated with the opening of the North Atlantic led to renewed sediment influx in the Aptian (Oakman 2005). During this phase, the Kopervik fairway was established (Law et al. 2000) along which large amounts of sand were transported from the East Orkney High to the outer Moray Firth, where the Britannia Field is situated (Ainsworth et al. 2000), before an Albian transgression diminished sand influx (Oakman \& Partington 1998; Jeremiah 2000).

These deposits comprise of deep marine sandstones exhibiting a variety of depositional styles including hanging-wall slope-apron fans, linear channel complexes as part of a minibasin spilling system, or localised mass flow deposits and mud-dominated slurry-flow deposits (Jones et al. 1999; Argent et al. 2000). These sedimentary systems demonstrate a high degree of complexity regarding source and transport mechanisms (Eggenhuisen et al. 2010). Deposition was strongly influenced by the two Early Cretaceous tectonic phases mentioned above which uplifted and exposed highs and fault scarps, as documented to the north and northwest of the main depocenters (e.g. Halibut Horst, East Orkney High, O'Driscoll et al. 1990; Copestake et al. 2003; Jeremiah 2000, Fig. 1a). Tectonic activity furthermore modified the region's bathymetry and redirected sediment transport fairways (Jeremiah 2000; Aas et al. 2010). These deep marine sandstones represent Lower Cretaceous reservoirs in stratigraphic or combination structural/stratigraphic traps in for instance the Britannia, Scapa and Captain fields (McGann et al. 1991; Jones et al. 1999; Pinnock et al. 2003).

Although the Forties-Montrose High and Marnock Terrace formed barriers that separated the UKCG depocenters from the Moray Firth during the Early Cretaceous (Fig. 1a), it is possible to extend the Lower Cretaceous Moray Firth reservoir intervals into the UKCG (MiltonWorssell et al. 2006) where various wells encounter Lower Cretaceous sands. This well data, in combination with seismically-derived maps, allowed Milton-Worssell et al. (2006) to 
postulate the distribution of (mainly deep marine sandstone) bodies, sourced by the Western Platform, Forties-Montrose High and Jæren High, for both a Latest Ryazanian-Barremian play and the Aptian-Albian play in the UKCG. These plays are separated by the Fischschiefer Bed (Fig. 2), an organic-rich mudstone deposited during the Barremian flooding event, that is a regional seismic marker (Ainsworth et al. 2000). In this study, a similar division has been made between a "Latest Ryazanian" interval (near BCU-level) and an "Aptian-Albian" interval (near Top Lower Cretaceous level) to extend the scope into the NCG and to acquire a North Sea-wide overview (Fig. 2).

\section{DATA AND METHODS}

2D and 3D seismic datasets, provided by Shell Upstream International, combined with data from 474 wells were used to establish a structural framework in the study area (Fig. 1). The 3D data (extent: 11,400 $\mathrm{km}^{2}$ ) are a compilation of the Norwegian Carmot dataset, covering the NCG, and part of the UK Megamerge dataset, covering a limited area part of the southern UKCG (Fig. 1). The quality is variable but typically consists of dominant frequencies of ca. 20-30 Hz, a wavelength of ca. $60 \mathrm{~ms}$ two-way travel time (TWT) with a resulting seismic resolution of ca. $15 \mathrm{~ms}$ TWT. This corresponds to ca. $30 \mathrm{~m}$ vertical resolution assuming an interval velocity of $3500 \mathrm{~m} / \mathrm{s}$. Water depths range from 40 to $100 \mathrm{~m}$.

Data concerning 319 Norwegian wells in the study area were obtained from the Norwegian Petroleum Directorate (NPD) Factpages (NPD 2017). Additional well data for the UK and Danish sectors (119 and 41 wells, respectively) are from released well log and completion reports, well logs in the Shell archive (e.g. Boirie \& Jeannou 1984; Statoil 1991) and published material (e.g Isaksen \& Tonstad 1989, see table 1). Additional occurrences of Lower Cretaceous sandstones in UKCG wells are adopted from Milton-Worssell et al. 2006).

The following regional seismic horizons were mapped in two way time (TWT) on 3D seismic and calibrated with time-converted (via well checkshots and calibrated sonic logs) lithostratigraphically defined well tops from the Shell database and the NPD (Fig. 2):

- $\quad$ Base Cenozoic, (64 Ma);

- Top Lower Creteaceous (100 Ma);

- Base Cretaceous Unconformity (BCU, $140 \mathrm{Ma}$ );

- Top Rotliegend (270 Ma).

Milton-Worrsell et al. (2006) mapped the Fischerbank Schiefer Bed, which defines the boundary between their two Lower Cretaceous plays (Fig. 2). In this study this marker could not be traced due to a lack of accurately constrained well picks. The time maps of the four interpreted seismic horizons are combined with existing digital TWT seismic horizon maps provided by Shell Upstream International that allow an extension of the survey further into British and Danish territorial waters (study area, Fig. 1). A time difference assessment between the seismic horizons yields isochron maps, illustrating where the thickest sequences within the Cenozoic, Upper Cretaceous and Lower Cretaceous intervals are situated, revealing the general structural trends in the study area (Figs. 3 and 4). Due to the large study 
area, no time to depth conversion was carried out which means these structural trends are somewhat qualitative.

Two more lithostratigraphically-contstrained horizons have been mapped in TWT on five additional regional 2D seismic transects to provide an additional link to previous studies (S1S5, Figs. 1, 2, 5):

- Base Upper Jurassic (ca. $165 \mathrm{Ma}$ );

- Top Zechstein (252 Ma).

Although the available seismic coverage does not include Denmark, an earlier study (Møller \& Rasmussen 2003) provides a useful additional transect across the Danish border (S6, Fig. 5f). In combination with the seismic horizon time and isochron maps, these transects offer a detailed insight into the structural framework of the extended study area, revealing the locations of the main basins, highs, diapirs and faults (Figs. 3-5). Subsequently, the results of the seismic interpretation are integrated with published data from Copestake et al. (2003), Japsen et al. (2003), Milton-Worrsell et al. (2006) and Rossland et al. (2013) for an assessment of Lower Cretaceous reservoir potential in the extended study area, of which well data provide a first impression (Figs. 4 and 6).

The basic methodology applied by Milton-Worssell et al. (2006) has been adopted. Combined isochron maps of the extended study area indicate zones with thin Lower Cretaceous deposits, which were potentially exposed and prone to erosion during the Early Cretaceous (Fig. 7). At these places, well data provides the true thickness of the Lower Cretaceous sequence and the lithology in subcrop below the BCU. Devonian metamorphic rocks and volcanics, Rotliegend, Triassic Skagerrak, Middle Jurassic Bryne and Upper Jurassic Ula sandstones (Fig. 2) in subcrop indicate whether a specific locality was part of a potential sand source area during the Earliest Cretaceous. The presence of sand provenance areas is considered the most important factor controlling sandstone development since the Early Cretaceous was dominated by pelagic mud deposition (Fig. 2). This exercise is repeated for the Aptian-Albian reservoir interval, where the sand-prone lithologies in subcrop below the Top Lower Cretaceous horizon are charted (Fig. 8). The isochron maps subsequently allow the tracing of possible sediment transport fairways, by interpreting depocenters as drainage areas and barriers separating them as watersheds. Sediment transport is assumed to have followed the bathymetry given by the isochron maps, leading sediments from the highs to the depocenters. Thus, combining the isochron map, drainage and sand source areas; potential sand transport routes for the Latest Ryazanian and the Aptian-Albian are mapped (Figs 7 and 8). Well data allows a qualitative check of these interpretations: where sandstones occur in wells, a plausible link with a nearby sand source area can be inferred. If no such well data is available, sediment transport between source and depocenter remains speculative. It is recognised that the sandstones recorded in these wells are not necessarily linked to the postulated source areas and that those links would need to be proven via further investigation involving advanced seismic and well analysis techniques that are beyond the scope of this study. 
In general, a series of NNW-SSE orientated en-echelon (rift) basins, normal faults and tilted fault blocks follow the larger NW-SE Central Graben trend (Fig. 1, 3-5). The NCG structure is bounded by the Sørvestlandet High and the Ringkøbing-Fyn High to the east and by the Mid North Sea High to the south-west (Figs. 3-4).

The main depocenters, as identified on the isochron maps, are situated in the Breifflab Basin in the NW (Fig. 4a, 5, S1), where up to $8 \mathrm{~km}$ of subsidence has occurred (NDD 2012). However, the locations of these depocenters do not coincide with the thickest Upper Jurassic deposits in the SE part of the Feda Graben, Søgne Basin and Gertrud Graben (Erratt et al. 1999, Fig. 5, S5, S6). This discrepancy is a result of later differential thermal subsidence and sediment infill (Gowers \& Sæbøe 1985). Normal faults are omnipresent in the area, but major differences in structural style occur between the Pre-Zechstein units, Triassic, Upper Jurassic, Lower Cretaceous syn-rift strata and post-rift infill. The Josephine High (Fig. 5, S1), Hidra High (Fig. 5, S2), Border High (Fig. 5, S4), Mandal High (Fig. 5, S5, S6) Cod Terrace (Fig. 5, S1) and Piggvar Terrace (Fig. 5, S5) represent Pre-Zechstein basement blocks forming major structural highs or terraces. Several large salt domes occur within the area (e.g. Fig. 5, S1).

\section{Late Jurassic-Early Cretaceous rift structures}

Due to Mid-Jurassic thermal doming and associated erosion, few Lower Jurassic units are preserved in the study area. In contrast, significant Upper Jurassic sediments, recording the latest North Sea rift phase, occur locally in extensional basins. These units are best developed in the south of the study area, where the Feda Graben, Gertrud Graben and Søgne Basin halfgraben accommodate some $2 \mathrm{~km}$ of Upper Jurassic sequences (Fig. 5, S5, S6) as part of the large-scale left-stepping en-echelon Central Graben structure (Erratt et al. 1999, Fig. 1a). Many Triassic faults affect Upper Jurassic strata, indicating fault reactivation, e.g. the Skrubbe Fault and Coffee Soil Fault bounding the Feda Graben and Søgne Basin, respectively (Fig. 5, S5, S6). Rifting caused salt movement and diapirism which impacted Upper Jurassic sedimentation e.g. in the Søgne Basin.

Subsequently, the major Lower Cretaceous deposits are shifted westward compared to the Upper Jurassic depocenters (Figs. 5, S1, S3, S4). A distinct feature is the Early Cretaceous reactivation of the Pre-Zechstein half-graben west of the Border High, where Upper Jurassic or Triassic units are absent (Fig. 5, S4). Also striking is the lack of Early Cretaceous tectonic activity in the Søgne Basin; in contrast to significant Triassic and Upper Jurassic syn-tectonic units, little to no Lower Cretaceous sediments occur (Fig. 4b, 5, S5, S6).

The character of the Early Cretaceous basins varies considerably. The Border High and Breiflabb Basins are fault-bounded and show thickening towards the boundary faults, indicating syn-rift deposition (Fig. 5, S1, S4). Other rift-bounded basins are found west of the Hidra High (Fig. 5, S2), at well NO 2/4-10 (Fig. 5, S3) and west of the Mandal High (Fig. 5, S6). Yet the filling of pre-existing deep underfilled Jurassic basins as well as sediment compaction effects could partially account for these observations (Rattey \& Hayward 1993; 
275 Coward et al. 2003). At various localities, salt motion affected Early Cretaceous deposition:

276 e.g. above the Hidra High (Fig. 5, S2) and at well NO 2/4-3 (Fig. 5, S4). In other parts of the 277 study area, depocenters exhibit sag-type geometries, e.g. east of well UK 30/17B-3 and above 278 the Hidra High (both in Fig. 5, S2), west of the NO 1/6-5 diapir (Fig. 5, S3) and in the Ål 279 Basin (Fig. 5, S5, S6). Faults do not generally continue to the top of the Early Cretaceous, 280 except for those associated with later tectonic inversion.

281 As such, cessation of rifting is shown to be diachronous. The westward shift of the Early Cretaceous depocenters with respect to the Jurassic rifts might indicate a change in extensional regime near the start of the Cretaceous, as proposed by previous authors (e.g. Erratt et al. 1999), before extension activity ceased altogether due to the opening of the young North Atlantic (Rattey \& Hayward 1993).

\section{Post-rift and tectonic inversion structures}

The Late Cretaceous and Cenozoic units dominantly show gentle sag geometries along the NW-SE trend of the NCG, indicating further post-rift thermal subsidence. At the Breiflabb basin on the UK/Norwegian border, thermal subsidence was strongest creating a major Late Cretaceous/Cenozoic depocenter (Figs. 4a, 5, S1, 6a, Gowers \& Sæbøe 1985). However, signs of inversion are also noted, for instance at the Lindesnes Ridge where Early Cretaceous syn-rift deposits are uplifted along Skrubbe Fault, (Figs. 5, S1, 6e). Inversion-related structures (inverted grabens and diapirs/salt domes) disturb not only the Upper Cretaceous deposits, but also Cenozoic strata (Figs. 3-5), indicating multiple inversion phases (Gowers et al. 1993).

\section{LOWER CRETACEOUS RESERVOIR INTERPRETATION}

\section{Sandstone occurrences in Norwegian and Danish wells}

In contrast to the UKCG, where numerous wells encounter Lower Cretaceous sandstones (Milton-Worssell et al. 2006), only three wells in the NCG area (from a total of 160 Lower Cretaceous penetrations) are reported to contain similar deposits (NPD 2017, Figs. 4b, 6). The sandstones in these wells are lithostratigraphically defined as Ran Sandstone units (NPD 2017) and, in contrast with the deep marine character of most equivalent Lower Cretaceous sandstones in the UK, are interpreted as shallow submarine fans (Isaksen \& Tonstad 1989; Milton-Worssell et al. 2006).

Well NO 2/1-8 on the Cod Terrace contains a 4 m interval of Ran Sandstones, but no further details on lithology, or reservoir properties are publicly available (Fjellanger 1986; NPD 2013). These sandstones appear below the Hauterivian-Barremian Tuxen Fm and are, therefore, assigned to the Ryazanian reservoir interval (Fig. 2). Reference well NO 2/7-15 in the Feda Graben (Isaksen \& Tonstad 1989, Fig. 4b) contains a 48 m thick Ran Sandstone sequence. Cores taken from the lowermost part of this succession are described as dominantly clay-rich siltstones with occasional micro-porosity and fractures with minor hydrocarbon shows (Phillips 1981). However, drill stem tests demonstrated the section to be tight (NPD 2017). The age of these Ran Sandstones is poorly constrained, but they are 
314 attributed to the Albian-Aptian reservoir interval due to their occurrence directly below the

315 Aptian-Albian Sola Fm (Isaksen \& Tonstad 1989, Fig. 2).

316 In well NO 3/7-3, east of the Mandal High (Fig. 4b), a 107 m thick Ran Sandstone sequence 317 occurs on top of the BCU (NPD 2017). These deposits consist of a lower unit of dolomitic 318 and glauconitic sandstones, interbedded with dolomitic and shaley layers, and an upper unit 319 of massive coarse-grained sandstones with occurrences of chalky, sandy limestone, capped 320 by carbonates containing some lignite (Verolles 1982). The massive sandstones (60-70\% quartz) are cemented but represent good reservoir potential with porosities and permeabilities between 20-28\% and 0.5 to 10 D respectively (Verolles 1982; Boirie \& Jeannou 1984). The NO 3/7-3 Ran Sandstones were deposited as lenticular sheets or slope apron bodies in a restricted and proximal, relatively shallow marine environment (100-200 $\mathrm{m}$ water depth, Verolles 1982), which evolved into an open marine setting towards the end of the Early Cretaceous (Boirie \& Jeannou 1984). Since the Ran Sandstones are of Ryazanian age (Boirie \& Jeannou 1984), they belong to the Latest Ryazanian reservoir interval.

328 Four other Norwegian wells encountering Ran Sandstone are situated to the NE, in block 17, at a considerable distance from the North Sea rift basins and outside the extended study area. The implications of these sandstone occurrences will be addressed in the South Viking Graben regional overview below.

In the Tail End Graben (Denmark), 9 m thick Lower Cretaceous subangular to subrounded and poor to moderately sorted, fine grained "Kira Sandstones" are found above BCU-level in the Amalie-1 well, probably deposited as part of a submarine fan system (Statoil 1991, Fig. 6). These sandstones are oil-bearing and of excellent reservoir quality with high porosities and permeabilities $(0.213$ and $319 \mathrm{mD}$, respectively) and a net-to gross ratio of 0.339 (Statoil 1991). Further Latest Ryazanian sandstones, although thinner, occur in the Tabita-1, Svane-1 and Iris-1 wells south of the Amalie-1 well (Figs. 4b). The Tabita-1 "Kira Sandstone equivalent" at the base of the Lower Cretaceous contains mostly claystone with very fine grained silt- and (quartz) sandstone striae $(1-3 \mathrm{~cm})$, as well as cross bedding with erosional surfaces (Bonde et al. 1994). A core from this interval contains conglomeratic intervals of unweathered, angular clasts of metamorphic basement material, as well as folded and disturbed mudstone beds. Both facies are indicative of slope process, whilst the lack of waverelated structures in the core suggests a depositional environment below storm wave base (Bonde et al. 1994). In the Svane-1 well, very fine to fine grained, subrounded, poorly sorted calcareous quartz sandstones with an argillaceous matrix and net-to-gross ratios up to 0.85 are found above the BCU (Thorsrud et al. 2002). The Iris-1 well contains various levels of thin sandstone in the Valhall Fm overlying the BCU which are "a few" meters thick (Britoil 1985). The cored material from this well is predominantly fine-grained and similar to that in the Tabita-1 well (Bonde et al. 1994). Further to the west, Lower Cretaceous (Latest Ryazanian-Early Hauterivian) fine to medium grained, poorly sorted sandstones, belonging to the Latest Ryazanian reservoir interval, are present in the Sten-1 well (Kern et al. 1983), making a total of 5 wells encountering Lower Cretaceous sandstones in the Danish part of the study area (Fig. 4b). 
An interpretation of the Latest Ryanazian reservoir interval is presented in Fig. 7 and depicts the sandstone occurrences in wells, potential source areas with sand-prone lithologies subcropping the BCU and sediment transport fairways to depocenters identified on the Lower Cretaceous isochron map.

Milton-Worrsell et al. (2006) demonstrated the potential for marine sandstone development in the Ryazanian-Barremian interval of the UKCG, with the Forties-Montrose High and Western Platform interpreted as provenance areas. Closer to the Norwegian-British border, sand-prone lithologies are found in subcrop below the BCU at the Josephine High (Skagerrak Fm), Auk Ridge (Rotliegend) and Argyll Field at the Mid North Sea High (Rotliegend, Ula Fm and Skagerrak Fm). These represent potential sand source areas for the surrounding depocenters where multiple well penetrations occur (Milton-Worrsell et al. 2006). The Auk Ridge is also the likely provenance area for the Lower Cretaceous Devil's Hole Sandstones to its west (Milton-Worssell et al. 2006). These scattered deposits are considered similar to the Norwegian Ran Sandstones (Isaksen \& Tonstad 1989) and possibly represent a continuation of the Upper Jurassic syn-rift Fulmar/Ula shoreface or shelf deposits (Bisewski 1990; Johnson \& Lott 1993; Copestake et al. 2003, Fig. 2). The UK Flora-Fife Trend area and the Danish Inge High contain Ula Fm and Rotliegend units in subcrop below the BCU. These are potential source areas for the sandstones in the Danish Sten-1 well (Kern et al. 1983), which is situated in a Lower Cretaceous depocenter (Fig. 7) and is postulated to be a deep marine deposit.

The $4 \mathrm{~m}$ thick unspecified sandstone layer in well NO 2/1-8 (NPD 2013) represents an isolated Ran Sandstone occurrence on the Cod Terrace (Fig. 2, 6). The most probable origin would be either the Mandal High or the Cod terrace, where well 7/11-8 encounters the Skagerrak Fm. in subcrop below the BCU (NPD 2017), indicating a possible small-scale sediment provenance area. Any material originating from the Scandinavian mainland to the NE would most likely be caught in the Norwegian-Danish Basin region, where major Lower Cretaceous depocenters are situated (Copestake et al. 2003, Fig. 1a). Similarly, sediments from the Josephine High would first have had to cross the Breifflab Basin depocenters (Fig. 7). However, the exact nature and provenance of these Ran Sandstones cannot be established with the data currently available.

The thickest Ran sandstones in the study area occur in well NO 3/7-3 (107 m, Fig. 6) and these relatively shallow to open marine sandstones were deposited just in the Søgne Basin (Verolles 1982; Boirie \& Jeannou 1984), which was tectonically inactive during the Lower Cretaceous (Rossland et al. 2013, Figs. 5, S5, S6). The adjacent Mandal High and its metamorphic basement units were largely exposed during the Early Cretaceous (Verolles et al. 1982; Copestake et al. 2003; Rossland et al. 2013, Fig. 7, 9) and are the probable source for these proximal Ran Sandstones (Verolles 1982). Alternatively, Rossland et al. (2013) suggest, on the basis of dip directions, that these sandstones are related to a turbidite system sourced from the Rynkøbing-Fyn High to the east. It should however be stressed that their dip-meter data may be affected by post-sedimentary salt movement associated with the large salt dome below the Søgne Basin (Verolles 1982, Figs. 5, S5, S6), or could simply represent a 
deviation in transport direction as frequently observed within local submarine fan systems (e.g. Normark et al. 1979).

The presence of the thick Ran Sandstones in well NO 3/7-3 (Boirie \& Jeannou 1984) indicate promising reservoir development in the area, yet none of the other wells in the vicinity encounter Lower Cretaceous sandstones (NPD 2017, Fig. 9). This is in accordance with the depositional character of the Ran Sandstone units described by Verolles (1982) and Boirie \& Jeannou (1984), who suggest that reservoir bodies in the area, although potentially of significant thickness, may have a restricted lateral extent (Figs. 9). Furthermore, the Mandal High area is little studied, potentially harbouring reservoirs in various other stratigraphic intervals (Rossland et al. 2013, Fig. 10) and detailed analysis will be required to identify these.

In the east of the study area, the Kira Sandstones and their equivalents in the Amalie-1 and Tabita-1 wells (Fig. 6) probably represent submarine fan or slope deposits (Statoil 1991), associated with erosion at BCU-level and the nearby boundary fault between the Tail End Graben and the Ringkøbing-Fyn High (Bonde et al. 1994, Fig. 7). Although no rock samples are available from the Amalie-1 well, the metamorphic clasts in cores from the Tabita- 1 well are reported to be similar to the basement rocks on the Ringkøbing-Fyn High and on the Mandal High (well NO 3/7-1) (Bonde et al. 1994). Possible supply from the Ringkøbing-Fyn High may have involved submarine erosion of the footwall basement, whereas alternative sediment transport from the Mandal High may have by-passed the NO 3/7-3 well and Amalie-1 well before reaching the Tabita-1 well location (Bonde et al. 1994, Fig. 7). The sand-prone intervals in the Svane-1 and Iris-1 wells are possibly correlatable to the Kira Sandstones (Bonde et al. 1994; Thorsrud et al. 2002), which, if correct, may indicate a regional deep marine fan system (Fig. 7). It should be noted however, that except for the Amalie-1 well, no Lower Cretaceous reservoir-quality sandstones are found. Yet a few localised sandy apron or lobe units may have developed as a continuation of the Jurassic deep marine sandstones in the area (Bonde et al. 1994; Nielsen et al. 2015). Similar deposits could also have developed in the Gertrud Graben and Feda Graben to the South and SW of the exposed Mandal High (Rossland et al. 2013), but there is currently no evidence to support this interpretation and identifying such reservoirs, if present, will be highly challenging.

In contrast to the UK and Danish Central Graben areas, no Latest Ryazanian sandstones appear in wells within the NCG proper (NPD 2017) and most Lower Cretaceous depocenters are isolated from the identified sand source areas (Fig. 7). However, various faults were still active, of which some could have exposed sand-prone lithologies to erosion. Of these, the Hidra High block next to the Breifflab Basin, where Rotliegend units are present in the footwall, is the best example (Figs. 5b, 7). However, it is possible that such smaller sand source areas (e.g. Argyll Field area: $10-100 \mathrm{~km}^{2}$ and less for exposed fault scarps) might not have produced enough sand-prone material for reservoir-size deposits (sensu McArthur et al. 2016a). By contrast, the exposed Mandal High amounts to $500-600 \mathrm{~km}^{2}$ and is associated with the thick Ran sandstones in well NO 3/7-3 and the postulated Amalie fan system, thus representing significant reservoir potential. 


\section{Aptian-Albian reservoir distribution}

The interpretation of the Latest Ryazanian reservoir interval is presented in Fig. 8 and depicts the sandstone occurrences in wells, potential source areas with sand-prone lithologies subcropping the Top Lower Cretaceous and sediment transport fairways to depocenters identified on the Lower Cretaceous isochron map.

Towards the end of the Early Cretaceous, sandstone occurrences are rarely seen in UKCG wells (Milton-Worssel et al. 2006). However, important sediment provenance areas (e.g. the Forties-Montrose High, Auk Ridge, Josephine High) were still in place and exposed, providing sand influx into the adjacent depocenter as recorded in some penetrations (MiltonWorssell et al. 2006, Fig. 8). However, several of the smaller source areas were flooded and covered with Lower Cretaceous deposits (Cod Terrace and Inge High) and potential sourcing from fault scarps was strongly diminished with the cessation of rift activity. Other Ryazanian provenance areas were reduced but remained partially exposed towards the end of the Early Cretaceous as indicated by subcrop data (e.g. the Argyll Field area, Flora-Fife Trend, compare Fig. 8 with Fig. 7), yet no sandstone well occurrences are recorded in the adjacent Aptian-Albian depocenters.

Ran Sandstone units belonging to the Aptian-Albian reservoir interval are found in only one Norwegian well: NO 2/7-15 (Isaksen \& Tonstad 1989, NPD 2017, Figs. 6, 8). These clay-rich silt/sandstones are somewhat isolated from the interpreted sediment provenance areas. The Flora Field area, where the Rotliegend is found in subcrop below the Upper Cretaceous chalk deposits, is proposed as the most likely origin of these units (Fig. 8). However, the character of NO 2/7-15 Ran Sandstones remains poorly constrained and demands further assessment.

It should be noted that the wells in the Søgne Basin area, where thick Ryazanian Sandstones were previously deposited (well NO 3/7-3), record only mudstone and chalky deposits (Rossland et al. 2013; NPD 2017). Also, the potential Amalie fan system in the Danish Tail End Graben to the south is absent in well reports. Yet the Mandal High was still prone to erosion during the Aptian-Albian, as indicated by metamorphic basement and Bryne Fm subcropping the Upper Cretaceous chalk units (wells NO 2/6-5, NO 3/7-1 and West-Lulu 4, Mærsk 1987; NPD 2017). In addition, large parts of the Ringkøbing-Fyn High have no or thin (a few meters) Lower Cretaceous cover (Japsen et al. 2003). Both highs may, therefore, have produced sand-prone material leading to localised reservoir development (Fig. 8), although there is currently no evidence to support this suggestion.

Overall, the Aptian-Albian reservoir interval provides significantly less potential for Lower Cretaceous sandstone deposits than the Latest Ryazanian, due to the drowning of sand source areas. Still, the Ran Sandstone present in well NO 2/7-15 and the sandstone occurrences in various other wells in the UKCG indicate some reservoir potential. 


\section{POTENTIAL ANALOGUE SETTINGS IN THE SOUTHERN PERMIAN BASIN} AREA

This study shows that the UKCG and NCG harbour potential for Lower Cretaceous sandstone reservoir units suggesting further exploration possibilities. As the Central Graben structure continues south into Danish, German and Dutch territorial waters (Figs. 1, 11), where the geological setting was quite similar during the Early Cretaceous (Voigt et al. 2008; Pharaoh et al.2010), it would be worthwhile to extend the scope of a future case study to these areas.

In Denmark for example, the Ringkøbing-Fyn High along the Eastern margin of the Tail End Graben has no or limited Upper Jurassic to Lower Cretaceous sedimentary cover (Japsen et al. 2003), and is known to have been the source of various Late Jurassic fan deposits (Johannessen \& Andsbjerg 1993; Andsbjerg \& Dybkjær 2003). Such conditions are likely to have continued into at least the Earliest Cretaceous, as illustrated by the deposition of Vyl sandstones (Figs. 2, 11a). These submarine fan units with moderate reservoir potential are found adjacent to the Coffee Soil Fault and were supplied by the Ringkøbing-Fyn High (Michelsen et al. 2003, Fig. 11a). In addition, the Lower Cretaceous chalks of the Tuxen Fm. form the reservoirs in the Danish Valdemar and Adda fields (Copestake et al. 2003; Jakobsen et al. 2005, Fig. 2) indicating another attractive target for continued exploration in the area.

Further to the south, the German and Dutch sectors of the Central Graben are flanked by the Schill Grund High to the east and the Step Graben and Cleaver Bank High to the west (Fig. 11a), areas which were exposed highs during the Late Jurassic and the Early Cretaceous (Pharaoh et al. 2010). However, intense Late Cretaceous and Cenozoic basin inversion has caused significant erosion (De Jager 2007) and most of the Lower Cretaceous in the southern sector of the Dutch Central Graben was removed. In the northern sector of the Dutch Central Graben, where inversion and associated erosion was less drastic (Dronkers \& Mrozek 1991), Lower Cretaceous sediments are better preserved and hydrocarbon-bearing Scruff sandstones are found (De Jager 2003; De Jager \& Geluk 2007, Fig. 2). Additionally, the adjacent Terschelling Basin, where moderate inversion is recorded (Verweij \& Witmans 2009) contains relatively thick Lower Cretaceous deposits (Duin et al. 2006; EBN et al. 2015).

On the southern fringes of the Southern Permian Basin, the Broad Fourteens Basin and West Netherlands Basin form a continuation of the Lower Cretaceous North Sea basins (Fig 11a). Although these basins also underwent strong post-rift inversion (Van Wijhe 1987; De Jager 2003), significant parts of the Lower Cretaceous deposits are preserved in the area (over 900 m thick locally, Duin et al. 2006) and contain various hydrocarbon fields (De Jager \& Geluk 2007). Similar to the situation in the Moray Firth, the associated reservoirs are documented to be visible on seismic due to a relatively thin Upper Cretaceous-Cenozoic overburden (Oakman 2005). The Early Cretaceous depositional environment was, however, rather different from the situation in the Central Graben and Moray Firth. Instead of isolated shaledominated basins, receiving limited sand influx from small exposed highs nearby, the area received ample sediment input from the large London-Brabant Massif to the south (Jeremiah et al. 2010, Fig. 11a). Therefore, extensive continental to shallow marine shelf clastics were deposited in relatively shallow basins, in contrast with the deep marine basin settings in the Central and Northern North Sea (Figs. 2, 11). The abundance of sand-prone material in the 
depositional systems on the fringe of the Southern Permian Basin could potentially have fed submarine fans in the rift depocenters further north. The area experienced tectonicallyinduced rejuvenation of clastic input, progradation and the development of a widespread shelf system at the K30 sequence boundary, which is associated with increased Hauterivian deep marine reservoir development in the Moray Firth (DeVault \& Jeremiah 2002). However, except for the Lower Barremian (Wanneperveen) turbidite units found in association with the Friesland Platform near the Dutch-German border (Jeremiah et al. 2010, Fig. 11a), no such deposits are recorded in the Southern Permian Basin. This scarcity of deep marine sand development may be related to the area's relatively gentle bathymetry during the Early Cretaceous (Fig. 11a) although various other factors are known to affect turbidite systems such as shelf width, surrounding geomorphology and hinterland lithologies (Martinsen et al. 2005; Mudge 2014).

\section{ANALOGUE SETTINGS IN THE SOUTH VIKING GRABEN AREA}

Another potential analogue region to the NCG is the South Viking Graben (SVG, Fig. 11). In contrast to the Southern North Sea, the area was associated with a deep marine setting (flanked by exposed highs) during the Earliest Cretaceous (Fig. 11a). Shallow marine or terrestrial sandstones were deposited on the Utsira High, forming parts of the reservoirs in the Edvard Grieg and Johan Sverdrup fields (NPD 2017) and may be directly comparable to the Mandal High in the NCG (Rossland et al. 2013). The SVG is documented to include Upper Jurassic turbidites (Partington et al. 1993; Fraser et al. 2003; Jackson et al. 2011). The associated Fladen Ground Spur, Crawford Spur and Utsira High sand provenance areas continued to be exposed in the earliest Cretaceous (Copestake et al. 2003, Fig 11a). However, no Earliest Ryazanian deep marine sands are reported from the SVG area, potentially providing exploration opportunities.

The situation was different during the Aptian, where Skiff Sandstone units are reported along the fringes of the Fladen Ground Spur and the Crawford Spur (Johnson \& Lot 1993; Johnson et al. 2005, Fig. 11b). To the south, the Kopervik fairway supplied the reservoirs of the giant Britannia Field with sands derived from the East Orkney High in the west (Jeremiah 2000). Oakman (2005) suggests that these deep marine sands represent a fundamentally different depositional system for the Aptian-Albian interval, rather similar to the Cenozoic situation and involving sediment transport over long distances sourced by the exposed North Atlantic rift shoulders, in contrast to the preceding confined Upper Jurassic turbidite fans. The Kopervik system is, however, separated from the SVG by a halokinetically-induced high that was in place throughout the Early Cretaceous, so that potential sandstone deposits in the SVG can only be derived from the adjacent highs (Bisewski 1990, Fig, 11). Further to the north, in the North Viking graben, deep marine slumps of Albian age form reservoirs of the Agat field Skibeli et al. 1995) but these deposits were derived from the main Scandinavian massif (Gulbrandsen \& Nyborkken 1991), whereas the SVG remained relatively isolated.

Other wellbore calibrated sandstone occurrences in the area are reported from the Asta Graben, SE of the Utsira High (3-6 in Fig. 11b, Table 1). These Ran Sandstone units all occur 
565 in the uppermost part of the Lower Cretaceous, directly underneath the Upper Cretaceous chalk deposits and were likely deposited in a shallow marine environment (Olsen 1979; Isaksen \& Tonstad 1989).

\section{POTENTIAL METHODS FOR FURTHER DETAILED RESERVOIR INTERPRETATION}

As demonstrated by Milton-Worssell et al. (2006), detailed seismic analysis is required to distinguish potential reservoir units. However, the presence of thick Upper Cretaceous chalk and the low impedance contrasts between Cromer Knoll shales and sandstones renders seismic imaging of any relatively thin (typically less than $30 \mathrm{~m}$ ) Lower Cretaceous sandstone reservoir problematic. To do so requires good quality 3D seismic data combined with an understanding of the likely depositional systems to be encountered (Crittenden et al. 1998; Law et al. 2000; McKie et al. 2015). With such data available, sedimentary systems such as deep marine fans may be traceable on time slice amplitude maps (e.g. Posamentier \& Kolla 2003; Martinsen et al. 2005; Kilhams et al. 2011; 2014a). Amplitude versus offset (AVO) techniques could help to distinguish differences in lithology and reservoir fluid content (e.g. Oakman 2005; Veeken \& Rauch-Davies 2006; Milton-Worssell et al. 2008; Othman et al. 2017). Such a study would be recommended for the Tail End Graben area, as there is potential for small-scale reservoir development. Furthermore, the seismic response of Lower Cretaceous sandstone well occurrences in the NCG, as well as the UKCG where sandstones are more common (Milton-Worssell et al. 2006), should be compared to seismic facies in undrilled depocenters. Detailed seismic sequence stratigraphy of Lower Cretaceous depocenters could allow the identification of sea-level driven erosional unconformities on highs, associated with lowstand fans systems in basinal areas (sensu Posamentier \& Vail 1988).

Methods to further assess sand source areas and to localise associated shallow to deep marine sandstones might include palynological (or similar biostratigraphic) analysis of cored wells to determine to what degree a high was exposed (e.g. O'Driscoll et al. 1990; Mudge \& Jones 2004; McArthur et al. 2016a). Since cores from wells NO 2/7-15 and NO 3/7-3 are available (NPD 2017), magnetic analysis could provide sediment transport directions of these specific Early Cretaceous sandstone occurrences (Hailwood \& Ding 2000). Additional petrological and geochemical analysis of heavy minerals (e.g. garnets or zircons) might reveal their provenance area (e.g. Morton et al. 2005; Kilhams et al. 2014b; Nielsen et al. 2015), if cuttings/cores of nearby sand source areas are available (e.g. well NO 3/7-1 on the Mandal High and wells NO 3/7-3 and Tabita-1 in the Søgne Basin and Tail End Graben, respectively; Verolles 1982; Bonde et al. 1994, Fig. 7). Furthermore, it will be important to consider the factors influencing the behaviour and geometries of shoreface systems and deep marine fans (e.g. sand-to-mud ratio, flow discharge, slope gradient, sea level changes and fault activity) and where sand deposits occur in these systems (e.g. Posamentier \& Kolla 2003; Martinsen et al. 2005; McKie et al. 2015; McArthur et al. 2016b). Recently developed software for the simulation of turbidite deposition in combination with paleorelief reconstructions on $3 \mathrm{D}$ seismic could be a powerful tool to predict the distribution of deep marine fans (Aas et al. 2010). 
609 Here a structural framework of the NCG area has been presented. This reflects a diverse 610 geological history including Triassic extension and salt movement, Late Jurassic to Early 611 Cretaceous rifting and subsequent basin inversion with salt diapirism. Late Jurassic rifting 612 was most intense in the south of the study area, while Early Cretaceous rifting was more 613 important in the north, possibly representing an Early Cretaceous change in tectonic regime 614 before rifting halted altogether. An assessment of the Lower Cretaceous indicates fair 615 potential for reservoir development. Although the study area is isolated from a large 616 hinterland, local sediment sources and potential sediment transport routes are identified. Most 617 potential is expected around the exposed highs in Ryazanian times, while many sand source 618 areas were drowned at the end of the Early Cretaceous (Aptian-Albian). The underexplored 619 Mandal-High area, where restricted shallow marine sandstone deposits around the exposed 620 Mandal High and in the Søgne Basin provide the best potential, is suggested for further focus. 621 Similar depositional environments could have existed around other exposed highs (e.g. 622 Josephine High, Auk Ridge), although they may have been too small to have produced 623 significant reservoir units. Furthermore, the postulated Amalie fan system in Denmark 624 illustrates the possibilities for good quality deep marine sandstones, which may have also 625 formed in the depocenters south and SW of the Mandal High. Analogous settings to those in 626 the study area are also recognised in the Southern Permian Basin area to the south and the 627 South Viking Graben to the north, further analysis of the Lower Cretaceous reservoir 628 intervals of these areas would be an interesting next step. A detailed effort including the use 629 of advanced seismic techniques and detailed well analysis will be necessary to accurately 630 define such reservoirs, if present. The discovery of the Edvard Grieg and Johan Sverdrup 631 fields illustrates the importance of continued exploration, especially the re-assessment of 632 available well and seismic data, in the context of this mature hydrocarbon province (Jørstad 633 2012).

634

635

636

637

638

639

640

641

642

643

644 645
This project was originally undertaken as an internship at Shell Upstream International in Assen, Netherlands as the basis for a master's project (VU University Amsterdam). I would first like to express my gratitude to Carlo Nicolai and Ben Kilhams (Royal Dutch Shell) as well as Jan de Jager (VU University Amsterdam) for their support and guidance during this project and for helping me to prepare this manuscript for publication. I would also like to thank my colleagues from the Shell's UK/Netherlands Exploration Teams, the NAM IT team and colleagues from Shell Norway for their help and support. I am grateful to Adam McArthur and Jason Jeremiah for their detailed and constructive comments and to Royal Dutch Shell for funding this project and for allowing me to publish its results. 
646

647

648

649

650

651

652

653

654

655

656

657

658

659

660

661

662

663

664

665

666

667

668

669

670

671

672

673

674

675

676

677

678

679

680

681

682

683

684

685

686

687

\section{References}

A/S Norske Shell. 1968. Exploration Well Resumé. Well 17/11-1. A/S Norske Shell Exploration \& Petroleum Engineering Departments.

http://www.npd.no/engelsk/cwi/pbl/wellbore_documents/906_01_Exploration_well_resu me.pdf

Aas, T.E., Howell, J.A., Janocko, M. \& Jackson, C.A.-L. 2010. Control of Aptian palaeobathymetry on turbidite distribution in the Buchan Graben, Outer Moray Firth, Central North Sea. Marine and Petroleum Geology, 27, 412-434.

doi:10.1016/j.marpetgeo.2009.10.014

Ainsworth, N.R., Riley, L.A. \& Gallagher, L.T. 2000. An Early Cretaceous

lithostratigraphic and biostratigraphic framework for the Britannia Field reservoir (Late Barremian-Late Aptian), UK North Sea. Petroleum Geoscience, 6, 345-367.

DOI: $10.1144 /$ petgeo.6.4.345

Andsbjerg, J. \& Dybkjær, K. 2003 Sequence stratigraphy of the Jurassic of the Danish Central Graben. In: Ineson, J.R. \& Surlyk, F. (eds) The Jurassic of Denmark and Greenland. Geological Survey of Denmark and Greenland Bulletin, 1, Geological Survey of Denmark and Greenland Bulletin, 1, 265-300.

Argent, J.D., Stewart, S.A. \& Underhill, J.R. 2000. Controls on the Lower Cretaceous Punt Sandstone Member, a massive deep-water clastic deposystem, Inner Moray Firth, UK North Sea. Petroleum Geosciefjance, 6, 275-285. https://doi.org/10.1144/petgeo.6.3.275

Bartholomew, I.D., Peters, J.M. \& Powell, C.M. 1993. Regional structural evolution of the North Sea: oblique slip and the reactivation of basement lineaments. In: Parker, J.R. (ed) Petroleum Geology: North-West Europe and Global Perspectives - Proceedings of the 4th Petroleum Geology Conference. . Geological Society, London, Petroleum Geology Conference series, 4, 1109-1122.

DOI: $10.1144 / 0041109$

Bergan, M., Tørudbakken, B. \& Wandås, B. 1989. Lithostratigraphic correlation of Upper Jurassic sandstones within the Norwegian Central Graben: sedimentological and tectonic implications. In: Collinson, J. (ed) Correlation in Hydrocarbon Exploration. Graham \& Trotman, London, 243-251. DOI: 10.1007/978-94-009-1149-9_19

Bisewski, H. 1990. Occurrence and depositional environment of the Lower Cretaceous sands in the southern Witch Ground Graben. In: Hardman, R.F.P. \& Brooks, J. (eds), Tectonic Events Responsible for Britain's Oil and Gas Reserves. Geological Society Special Publication, 55, 325-338. 
Blackbourn, G.A. \& Thomson, M.E. 2000. Brittania Field, UK North Sea: petrographic constraints on Cretaceous provenance, facies and the origin of slurry-flow deposits. Petroleum Geoscience, 6, 329-343.

Bonde, K., Sandvik, R., Slot-Petersen, C. \& Olsen, T. 1994. Tabita-1, Tabita-1A Completion Report, Statoil Efterforskning OG Produktion A/S, Copenhagen, Denmark.

Boirie, J.M. \& Jeannou, A. 1984. Well 3/7-3 Lithostratigraphy and reservoir aspect of the pre-chalk sediments (Permian - Lower Cretaceous; Central Graben) Southern District Offshore Norway. Boussens well report, 062/84 RP.

http://www.npd.no/engelsk/cwi/pbl/wellbore_documents/293_03_3_7_3_LITHOSTRATI GRAPHY_AND_RESERVOIR_ASPECT_OF_THE_PRE-CHALK_SEDIMENTS.pdf

Britoil. 1985. Iris-1 composite well log. Britoil PLC. Exploration drawing office, Glasgow, UK.

Brooks, J. 1990. Classic petroleum provinces. In: Brooks, J. (ed) Classic Petroleum Provinces. Geological Society, London, Special Publications, 50, 1-8. DOI: 10.1144/GSL.SP.1990.050.01.01

Cartwright, J.A. 1989. The kinematics of inversion in the Danish Central Graben. In: Cooper, M. A., \& Williams, G. D. (eds) Inversion Tectonics. Geological Society, London, Special Publications, 44, 153-175. DOI: 10.1144/GSL.SP.1989.044.01.10

Copestake, P., Sims, A.P., Crittenden, S., Hamar, G.P., Ineson, J.R., Rose, P.T. \& Tringham, M.E. 2003. Lower Cretaceous. In: Evans, D., Graham, C., Armour, A. \& Bathurst, P. (eds) The Millennium Atlas: Petroleum Geology of the Central and Northern North Sea. Geological Society, London, 191-211.

Coward, M.P., Dewey, J.F., Hempton, M. \& Holroyd, J. 2003. Tectonic evolution. In: Evans, D., Graham, C., Armour, A. \& Bathurst, P. (eds) The Millennium Atlas: Petroleum Geology of the Central and Northern North Sea. Geological Society, London, 17-33.

Crittenden, S., Cole, J.M. \& Kirk, M.J. 1997. THE DISTRIBUTION OF APTIAN SANDSTONES IN THE CENTRAL AND NORTHERN NORTH SEA (UK SECTORS): A LOWSTAND SYSTEMS TRACT "PLAY”. Part 1. Stratigraphy, biostratigraphic age determination, and genesis of the sandstones. Journal of Petroleum Geology, 20 (1), 3-25.

Crittenden, S., Cole, J.M. \& Kirk, M.J. 1998. THE DISTRIBUTION OF APTIAN SANDSTONES IN THE CENTRAL AND NORTHERN NORTH SEA (UK SECTORS) A LOWSTAND SYSTEMS TRACT PLAY. Part 2. distribution and exploration strategy. Journal of Petroleum Geology, 21 (2), 187-211.

De Jager, J. 2003. Inverted Basins in the Netherlands, similarities and differences. Netherlands Journal of Geosciences/Geologie en Mijnbouw, 82, 4, 355-366. 
doi: https://doi.org/10.1017/S0016774600020175

De Jager, J. 2007. Geological Development. In: Wong, Th.E., Batjes, D.A.J. \& De Jager, J. (eds) Geology of the Netherlands. Royal Netherlands Academy of Science and Art, Amsterdam, 5-26.

De Jager., J. \& Geluk, M.C. 2007. Petroleum Geology. In: Wong, Th.E., Batjes, D.A.J. \& De Jager, J. (eds) Geology of the Netherlands. Royal Netherlands Academy of Science and Art, Amsterdam, 241-264.

DeVault, B. \& Jeremiah, J. 2002. Tectonostratigraphy of the Nieuwerkerk Formation (Delfland subgroup), West Netherlands Basin. AAPG Bulletin, 86 (10), 1679-1707. DOI: 10.1306/61EEDD50-173E-11D7-8645000102C1865D

Dronkers, A.J. \& Mrozek, F.J. 1991. Inverted basins of The Netherlands. First Break, 9, 409-425. DOI: 10.3997/1365-2397.1991019

Duin, E.J.T., Doornebal, J.C., Rijkers, R.H., Verbeek, J.W. \& Wong, Th. E. 2006. Subsurface structure of the Netherlands - results of recent onshore and offshore mapping. Netherlands Journal of Geosciences/Geologie en Mijnbouw, 85 (4), 355-366.

EBN, Ministry of Economic Affairs \& TNO, 2015. Prospectivity G and M blocks Analysing the Upper Jurassic play. http://www.nlog.nl/cmis/browser?id=workspace\%3A//SpacesStore/f84ec4ac-b9a6-47719212-6f6959233ead

Eggenhuisen, J.T., McCaffrey, W.D., Haughton, P.D.W., Butler, R.W.H., Moore, I., Jarvie, A., Hakes, W.G. 2010. Reconstructing large-scale remobilisation of deep-water deposits and its impact on sand-body architecture from cored wells: The Lower Cretaceous Britannia Sandstone Formation, UK North Sea. Marine and Petroleum Geology, 27, 1595-1615. doi:10.1016/j.marpetgeo.2010.04.005

Erratt, D., Thomas, G.M. \& Wall, G.R.T. 1999. The evolution of the Central North Sea Rift. Geological Society, In: Fleet, A.J. \& Boldy, S.A.R. (eds) Petroleum Geology: NorthWest Europe and Global Perspectives - Proceedings of the 5th Petroleum Geology Conference. Geological Society, London, Petroleum Geology Conference series, 5, 63-82. DOI: $10.1144 / 0050063$

Fjellanger, E. 1986. Geological Completion Report, Well 2/1-8. BP Petroleum Development (Norway) Ltd. U/A, Stavanger, Norway. http://www.npd.no/engelsk/cwi/pbl/wellbore_documents/459_2_1_8_Completion_report.p $\mathrm{df}$

Fraser, S.I., Robinson, A.M., Johnson, H.D., Underhill, J.R. \& Kadolsky, D.G.A., Connell, R., Johannessen, P. \& Ravnås, R. 2003. Upper Jurassic. In: Evans, D., Graham, C., 
Armour, A. \& Bathurst, P. (eds) The Millennium Atlas: Petroleum Geology of the Central and Northern North Sea. Geological Society, London, 155-189.

Fossen, H., Dallman, W. \& Andersen, T.B. 2008. The mountain chain rebounds and founders. In: Ramberg, I.B., Bryhni, I., Nøttvedt, A. \& Rangnes, K. (eds) The Making of a Land - Geology of Norway. Norsk Geologisk Forening. 232-259.

Garrett, S.W., Atherton, T. \& Hurst, A. 2000. Lower Cretaceous deep-water sandstone reservoirs in the UK Central North Sea. Petroleum Geoscience, 6, 231-240. https://doi.org/10.1144/petgeo.6.3.231

Gautier, D.L. 2005. Kimmeridge Shales Total Petroleum System of the North Sea Graben Province. U.S. Geological Survey Bulletin, 2204-C.

https://pubs.usgs.gov/bul/2204/c/pdf/B2204C.pdf

Ge, Z., Gawthorpe, R.L., Rotevatn, A. \& Thomas, M.B. 2016. Impact of normal faulting and pre-rift salt tectonics on the structural style of salt-influenced rifts: the Late Jurassic Norwegian Central Graben, North Sea. Basin Research, 1-25. doi: 10.1111/bre.12219

Gowers, M.B. \& Sæbøe, A. 1985. On the structural evolution of the Central Trough in the Norwegian and Danish sectors of the North Sea. Marine and Petroleum Geology, 2, 298318. DOI:10.1016/0264-8172(85)90026-1

Gowers, M.B., Holtar, E. \& Swensson, E. 1993. The structure of the Norwegian Central Trough (Central Graben area). In: Parker, J.R. (ed) Petroleum Geology: North-West Europe and Global Perspectives - Proceedings of the 4th Petroleum Geology Conference. Geological Society, London, Petroleum Geology Conference series, 4, 1245-1254. DOI: $10.1144 / 0041245$

Graversen, O. 2006. The Jurassic-Cretaceous North Sea Rift Dome and Associated Basin Evolution. AAPG Search and Discovery Article,\#3004. http://www.searchanddiscovery.com/documents/2006/06013graversen/images/graversen Gulbrandsen, A. \& Nyborkken, S. 1991. Agat Field - Norwegian North Sea, Subplatform North Viking Graben. AAPG Search and Discovery Article, \#91004. http://www.searchanddiscovery.com/abstracts/html/1991/annual/abstracts/0586b.htm

Hampson, J.M., Walden, S.F. \& Bell, C. 2010. Maximizing production and reserves from offshore heavy oil fields using seismic and drilling technology: Alba and Captain Fields, UKNS. In: Vining, B.A. \& Pickering, S.C. (eds) Petroleum Geology: From Mature Basins to New Frontiers - Proceedings of the 7th Petroleum Geology Conference. Geological Society, London, Petroleum Geology Conference series, 7, 337-347. DOI: $10.1144 / 0070337$ 
Hailwood, E. \& Ding, F. 2000. Sediment transport and dispersal pathways in the Lower Cretaceous sands of the Britannia Field, derived from magnetic anisotropy. Petroleum Geology, 6, 369-379. https://doi.org/10.1144/petgeo.6.4.369

Herngreen, G.F.W. \& Wong, Th.E. 2007. Cretaceous. In: Wong, Th.E., Batjes, D.A.J. \& De Jager, J. (eds) Geology of the Netherlands. Royal Netherlands Academy of Science and Art, Amsterdam, 127-150.

Hodgson, N.A., Fansworth, J. \& Fraser, A.J. 1992. Salt-related tectonics, sedimentation and hydrocarbon plays in the Central Graben, North Sea, UKCS. In: Hardman, R.F.P. (ed) Exploration Britain: Geological insights for the next decade. Geological Society, London, Special Publications, 67, 31-63. DOI: 10.1144/GSL.SP.1992.067.01.03

Isaksen, D. \& Tonstad, K. 1989. A revised Cretaceous and Tertiary lithostratigraphic nomenclature for the Norwegian North Sea. Norwegian Petroleum Directorate Bulletin, 5. http://www.npd.no/Global/Norsk/3-Publikasjoner/NPD-Bulletin/Bulletinnr5.pdf

Jakobsen, F., Ineson, J.R., Kirstensen, L., Nytoft, H.P. \& Stemmerik, L. 2005. The Valdemar Field, Danish Central Graben: field compartmentalization and regional prospectivity of the Lower Cretaceous chalk play. In: Doré, A.G. \& Vining, B.A. (eds) Petroleum Geology: North-West Europe and Global Perspectives - Proceedings of the 6th Petroleum Geology Conference. Geological Society, London, Petroleum Geology Conference series, 6, 177-186. https://doi.org/10.1144/0060177

Jackson, C.A.-L., Larsen, E., Hanslien, S., Tjemsland, A.-E. 2011. Controls on synrift turbidite deposition on the hanging wall of the South Viking Graben, North Sea rift system, offshore Norway. AAPG Bulletin, 95 (9), 1557-1587. DOI:10.1306/01031110037

Jackson, C.A.-L. \& Lewis, M.M. 2016. Structural style and evolution of a salt-influenced rift basin margin; the impact of variations in salt composition and the role of polyphase extension. Basin Research, 28, 81-102. doi: 10.1111/bre.12099

Japsen, P., Britze, P. \& Andersen, C. 2003. Upper Jurassic - Lower Cretaceous of the Danish Central Graben: structural framework and nomenclature. In: Ineson, J.R. \& Surlyk, F. (eds) The Jurassic of Denmark and Greenland. Geological Survey of Denmark and Greenland Bulletin, 1, 233-246. http://www.geus.dk/DK/publications/geol-survey-dk-glbull/Documents/nr1_p231-246.pd

Jeremiah, J.M. 2000. Lower Cretaceous turbidites of the Moray Firth: sequence stratigraphical framework and reservoir distribution. Petroleum Geoscience, 6, 309-328. DOI: 10.1144/petgeo.6.4.309

Jeremiah, J.M., Duxbury, S. \& Rawson, P. 2010. Lower Cretaceous of the southern North Sea Basins: reservoir distribution within a sequence stratigraphic framework. Netherlands Journal of Geosciences - Geologie en Mijnbouw, 89 (3/4). 203-237. 
Johannessen, P.N. \& Andsbjerg, J. 1993. Middle to Late Jurassic basin evolution and sandstone reservoir distribution in the Danish Central Trough. In: Parker, J.R. (ed) Petroleum Geology: North-West Europe and Global Perspectives - Proceedings of the 4th Petroleum Geology Conference. Geological Society, London, Petroleum Geology Conference series, 4, 271-283. doi: 10.1144/0040271 Knox, R.W.O'B. \& Cordey, W.G. (eds) Lithostratigraphic nomenclature of the UK North Sea. British Geological Survey (Nottingham).

878 http://www.bgs.ac.uk/downloads/start.cfm?id=2044

879 Jurassic, Upper Jurassic and Lower Cretaceous of the UK Central and Northern North Sea. British Geological Survey Research Report, RR/03/001.

883 http://nora.nerc.ac.uk/3680/1/RR03001.pdf Britannia Field, UK Central North Sea: modelling heterogeneity in unusual deep-water deposits. In: Fleet, A.J. \& Boldy, S.A.R. (eds) Petroleum Geology: North-West Europe and Global Perspectives - Proceedings of the 5th Petroleum Geology Conference. Geological Society, London, Petroleum Geology Conference series, 5, 1115-1124.

890 https://doi.org/10.1144/0051115 Sverdrup Discovery. AAPG Search and Discovery Article, \#20177. https://www.google $\cdot$ ch/url?sa=t\&rct=j\&q=\&esrc=s\&source=web\&cd=1\&cad=rja\&uact=8 \&ved=0ahUKEwiL4v6vwurVAhXGJMAKHXveBpQQFggyMAA\&url=http $\% 3 \mathrm{~A} \% 2 \mathrm{~F} \% 2$ Fwww.searchanddiscovery.com\%2Fdocuments \%2F2012\%2F20177jorstad\%2Fndx_jorsta d.pdf\&usg=AFQjCNErkXDHLyXjqcp8dlbV_ZJuqMtKYQ report. Chevron Petroleum Company of Denmark, Copenhagen, Denmark.

Kilhams, B., Godfrey, S., Harltey, A. \& Huuse, M. 2011. An integrated 3D seismic, petrophysical and analogue core study of the Mid-Eocene Grid channel complex in the greater Nelson Field area, UK Central North Sea. Petroleum Geoscience, 17, 127-142. DOI 10.1144/1354-079310-022

\section{Kilhams, B., Hartley, A., Huuse, M. \& Davis, C. 2014a. Characterizing the Paleocene} turbidites of the North Sea: Maureen Formation, UK Central Graben. . In: McKie, T., Rose, P.T.S., Hartley, A.J., Jones, D.W. \& Armstrong, T.L. (eds) Tertiary Deep-Marine Reservoirs of the North Sea Region. Geological Society, London, Special Publications, 403, 43-62. 
Kilhams, B., Morton, A., Borella, R., Wilkins, A., Hurst, A. 2014b. Understanding the provenance and reservoir quality of the Sele Formation sandstones of the UK Central Graben utilizing detrital garnet suites. In: Scott, R.A., Smyth, H.R., Morton, A.C. \& Richardson, N. (eds) 2014. Sediment Provenance Studies in Hydrocarbon Exploration and Production. Geological Society, London, Special Publications, 386, 129-142. https://doi.org/10.1144/SP386.16

Law, A., Raymond, A., White, G., Atkinson, A., Clifton, M., Atherton, T., Dawes, I.a.n., Robertson, E., Melvin, A \& Brayley, S. 2000. The Kopervik fairway, Moray Firth, UK. Petroleum Geoscience, 6, 265-274. DOI: 10.1144/petgeo.6.3.265

Lundin. 2017. Johan Sverdrup Development. Lundin Petroleum press releases. https://www.lundinpetroleum.com/download/ot_johansverdrup_present_e/?wpdmdl=6265/

Mærsk. 1987. Final Well Report West Lulu-4. Mærsk Olie OG Gas A/S Petroleum

Martinsen, O.J., Lien, T. \& Jackson, C.J. 2005. Cretaceous and Palaeogene turbidite systems in the North Sea and Norwegian Sea Basins: source, staging area and basin physiography controls on reservoir development. In: Doré, A.G. \& Vining, B.A. (eds) Petroleum Geology: North-West Europe and Global Perspectives - Proceedings of the 6th Petroleum Geology Conference. Geological Society, London, Petroleum Geology Conference series, 6, 1147-1164. https://doi.org/10.1144/0061147 459, 63-75. http://dx.doi.org/10.1016/j.palaeo.2016.06.033 Spatiotemporal relationships of deep-marine, axial, and transverse depositional systems from the synrift Upper Jurassic of the central North Sea. AAPG Bulletin, 100 (9), 14691500. DOI: $10.1306 / 04041615125$ 14/19, UK North Sea. In: Abbotts, I.L. (ed). United Kingdom Oil and Gas Fields, 25 Years Commemorative Volume. Geological Society, London, Memoirs, 14, 369-376. doi: 10.1144/GSL.MEM.1991.014.01.46

McKie, T., Rose, P.T.S., Hartley, A.J., Jones, D.W. \& Armstrong, T.L. 2015. Tertiary deep-marine reservoirs of the North Sea region: an introduction. In: McKie, T., Rose, P.T.S., Hartley, A.J., Jones, D.W. \& Armstrong, T.L. (eds) Tertiary Deep-Marine 
Reservoirs of the North Sea Region. Geological Society, London, Special Publications, 403, 1-16. DOI: $10.1144 /$ SP403.12

Michelsen, O., Nielsen, L.H., Johannessen, P.N., Andsbjerg, J. \& Surlyk, F. 2003 . Jurassic lithostratigraphy and stratigraphic development onshore and offshore Denmark. In: Ineson, J.R. \& Surlyk, F. (eds) The Jurassic of Denmark and Greenland. Geological Survey of Denmark and Greenland Bulletin, 1, 147-216. http://www.geus.dk/DK/publications/geol-survey-dk-gl-bull/Documents/nr1_p145216.pdf

Milton, N.J. 1993. Evolving depositional geometries in the North Sea Jurassic rift. In: Parker, J.R. (ed) Petroleum Geology: North-West Europe and Global Perspectives Proceedings of the 4th Petroleum Geology Conference. Geological Society, London, Petroleum Geology Conference series, 4, 425-442. DOI: 10.1144/0040425

Milton-Worssell, R.J., Stoker, S.J. \& Cavill, J.E. 2006. Lower Cretaceous deep-water sandstone plays in the UK Central Graben. In: Allen, M.R., Goffey, G.P. Morgan, R.K. \& Walker, I.M. (eds) The deliberate Search for the Stratigraphic Trap. Geological Society, London, Special Publications, 254, 169-186. DOI: 10.1144/GSL.SP.2006.254.01.09

Milton-Worssell, R., Fisher, G., Cameron, D., Stoker, S., Avu, A. \& Basford, H. 2008. WHERE ARE THOSE LOWER CRETACEOUS SANDS? GEOBODY DETECTION IN A DEPOCENTRE. PETEX conference proceedings, Petroleum Exploration Society of Great Britain (PESGB), London.

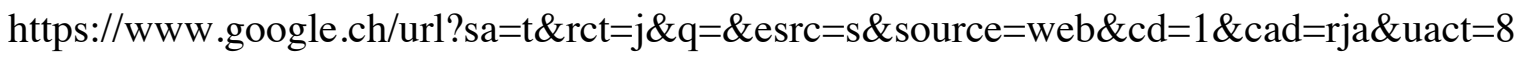
\&ved=0ahUKEwiK7qo8uzVAhXHC8AKHdqIClEQFggwMAA\&url=http\%3A\%2F\%2Fwww.geoteric.com\%2F hubfs\%2Fuploads\%2Fdownloads\%2FPETEX_2008.pdf\%3Ft\%3D1501511671995\&usg= AFQjCNE4aS36bSsk5ytaP10DBzZaFZ6hWg

Møller, J.J. \& Rasmussen, E.S. 2003. Middle Jurassic - Early Cretaceous rifting of the Danish Central Graben. In: Ineson, J.R. \& Surlyk, F. (eds) The Jurassic of Denmark and Greenland. Geological Survey of Denmark and Greenland Bulletin, 1, 247-264. http://www.geus.dk/DK/publications/geol-survey-dk-gl-bull/Documents/nr1_p247264.pdf

Morton, A.C., Whitman, A.G. \& Fanning, C.M. 2005. Provenance of Late Cretaceous to Paleocene submarine fan sandstones in the Norwegian Sea: Integration of heavy mineral, mineral chemical and zircon age data. Sedimentary Geology, 182, 3-28. https://doi.org/10.1016/j.sedgeo.2005.08.007

Mudge, D.C. \& Jones, S.M. 2004. Palaeocene uplift and subsidence events in the Scotland-Shetland and North Sea region and their relationship to the Iceland Plume. Journal of the Geological Society, London, 161, 381-386. https://doi.org/10.1144/0016-764903-038 
1002

1003

1004

1005

1006

1007

1008

1009

1010

1011

1012

1013

1014

1015

1016

1017

1018

1019

1020

1021

1022

1023

1024

1025

1026

1027

1028

1029

1030

1031

1032

1033

1034

1035

1036

1037

1038

1039

1040

1041

1042

1043

1044

Mudge, D.C. 2014. Regional controls on Lower Tertiary sandstone distribution in the North Sea and NE Atlantic margin basins. In: McKie, T., Rose, P.T.S., Hartley, A.J., Jones, D.W. \& Armstrong, T.L. (eds,) Tertiary Deep-Marine Reservoirs of the North Sea Region. Geological Society, London, Special Publications, 403.

https://doi.org/10.1144/SP403.5

NDD (Norway Discovery Digest). 2012. The HPHT and UHPHT Play in the Norwegian Central Graben. Canadian Discovery Ltd., 13, 12-33.

http://norwaydigest.canadiandiscovery.com/?q=node/33144

Nielsen, M.T., Weibel, R., Friis, H. 2015. Provenance of gravity-flow sandstones from the Upper Jurassice-Lower Cretaceous Farsund Formation, Danish Central Graben, North Sea. Marine and Petroleum Geology, 59, 371-389.

http://dx.doi.org/10.1016/j.marpetgeo.2014.09.016

Normark, W.R., Piper, D.J.W. \& Hess, G.R. 1979. Distributary channels, sand lobes, and mesotopography of Navy Submarine Fan, California Borderland, with applications to ancient fan sediments. Sedimentology, 26, 749-774. DOI: 10.1111/j.13653091.1979.tb00971.x

Nøttvedt, A. \& Johannessen, E.P. 2008. The source of Norway's oil wealth. In: Ramberg, I.B., Bryhni, I., Nøttvedt, A. \& Rangnes, K. (eds) The Making of a Land - Geology of Norway. Norsk Geologisk Forening, 384-417

NPD. 1979a. Interpreted lithology log. Well 7/3-1. NPD Paper, 20. http://www.npd.no/engelsk/cwi/pbl/NPD_papers/164_02_NPD_Paper_No.20_Interpreted _Lithology_log_Well_7_3_1.pdf

NPD. 1979b. Interpreted lithology log. Well 17/10-1. NPD Paper, 21. http://www.npd.no/engelsk/cwi/pbl/NPD_papers/161_02_NPD_Paper_No.21_Interpreted _Lithology_log_Well_17_10_1.pdf

NPD. 2013. Wellbore 2/1-8. Composite log.

http://www.npd.no/engelsk/cwi/pbl/wellbore_composite_logs/459.pdf

NPD. 2014. Lithostratigraphic Chart Norwegian North Sea. OD 1409001. http://www.npd.no/Global/Engelsk/2-Topics/Geology/Lithostratigraphy/NSOD1409001.pdf

NPD. 2017. (Norwegian Petroleum Directorate website and FactPages/Maps) www.npd.no and http://factpages.npd.no/factpages/Default.aspx?culture=en 
Oakman, C. D. \& Partington, M. A. 1998. Cretaceous. In: Glennie, K. W. (ed) Petroleum Geology of the North Sea-Basic Concepts and Recent Advances. 4th edition, Blackwell, Oxford, 294-349.

Oakman, C.D. 2005. The Lower Cretaceous plays of the Central and Northern North Sea: Atlantean drainage models and enhanced hydrocarbon potential. In: Doré, A.G. \& Vining, B.A. (eds) Petroleum Geology: North-West Europe and Global Perspectives Proceedings of the 6th Petroleum Geology Conference. Geological Society, London, Petroleum Geology Conference series, 6, 187-198. DOI: 10.1144/0060187

O’Driscoll, D., Hindle, A.D., \& Long, D.C. 1990. The structural controls on Upper Jurassic and Lower Cretaceous reservoir sandstones in the Witch Ground Graben, UK North Sea. In: Hardman, R.F.P. \& Brooks, J. (eds) Tectonic Events Responsible for Britain's Oil and Gas Reserves. Geological Society Special Publication, 55, 299-323.

Olsen, R.C. 1979. Lithology. Well 17/10-1. NPD Paper, 21.

http://www.npd.no/engelsk/cwi/pbl/NPD_papers/161_01_NPD_Paper_No.21_Lithology_ _Well_17_10_1.pdf

Othman, A.A.A., Bakr, A. \& Maher, A. 2017. Integrated seismic tools to delineate Pliocene gas-charged geobody, offshore west Nile delta, Egypt. NRIAG Journal of Astronomy and Geophysics, 6, 81-89. http://dx.doi.org/10.1016/j.nrjag.2017.04.008

Partington, M.A., Mitchener, B.C., Milton, N.J. \& Fraser, A.J. 1993. Genetic sequence stratigraphy for the North Sea Late Jurassic and Early Cretaceous: distribution and prediction of Kimmeridgian-Late Ryazanian reservoirs in the North Sea and adjacent areas. In: Parker, J.R. (ed) Petroleum Geology: North-West Europe and Global Perspectives - Proceedings of the 4th Petroleum Geology Conference. Geological Society, London, Petroleum Geology Conference series, 4, 347-370. doi: 10.1144/0040347

Pharaoh, T.C., Dusar, M., Geluk, M.C., Kockel, F., Krawczyk, C.M., Krzywiec, P., Scheck-Wenderoth, M., Thybo, H., Vejbæk, O.V. \& Van Wees, J.D. 2010. Tectonic Evolution. In: Doornenbal, J.C. \& Stevenson, A.G. (eds) Petroleum Geological Atlas of the Southern Permian Basin Area. EAGE Publications b.v., Houten, 25-58.

Phillips, 1981. Completion book for the exploratory well 2/7-15. Phillips Petroleum Company Norway. http://www.npd.no/engelsk/cwi/pbl/wellbore_documents/225_01_2_7_15_Completion_re port.pdf

Pinnock, S.J., Clitheroe, A.R.J. \& Rose, P.T.S. 2003. The Captain Field, Block 13/22a, UK North Sea. In: Gluyas, J.G. \& Hichens, H.M. (eds) United Kingdom Oil and Gas Fields, Commemorative Volume. Geological Society, London, Memoirs, 20, 431-441. doi: 10.1144/GSL.MEM.2003.020.01.35 
Posamentier, H.W. \& Vail, P.R. 1988. EUSTATIC CONTROLS ON CLASTIC DEPOSITION II-SEQUENCE AND SYSTEMS TRACT MODELS. In: Wilgus, C.K., Posamentier, H.W., Ross, C.A. \& Kendall, C.G.St.C (eds) Sea-level Changes: An Integrated Approach. SEPM, Special Publication, 42, 125-154.

Posamentier, H.W. \& Kolla, V. 2003. Seismic Geomorphology and Stratigraphy of Depositional Elements in Deep-Water Settings. Journal of Sedimentary Research, 73 (3), 367-388. DOI: 10.1306/111302730367

Provan, D.M.J. 1976. Composite Well Log 17/11-2. A/S Norske Shell. http://www.npd.no/engelsk/cwi/pbl/wellbore_documents/338_02_Composite_well_log.pd $\mathrm{f}$

Rattey, R.P. \& Hayward, A.B. 1993. Sequence stratigraphy of a failed rift system: the Middle Jurassic to Early Cretaceous basin evolution of the Central and Northern North Sea. In: Parker, J.R. (ed) Petroleum Geology: North-West Europe and Global Perspectives - Proceedings of the 4th Petroleum Geology Conference. Geological Society, London, Petroleum Geology Conference series, 4, 215-249. DOI: 10.1144/0040215

Ray, F.M., Pinnock, S.J., Katamish H. \& Trunbull, J.B. 2010. The Buzzard Field: anatomy of the reservoir from appraisal to production. In: Vining, B.A. \& Pickering, S.C. (eds) Petroleum Geology: From Mature Basins to New Frontiers - Proceedings of the 7th Petroleum Geology Conference. Geological Society, London, Petroleum Geology Conference series, 7, 369-386. DOI: 10.1144/0070369

Rossland, A., Escalona, A. \& Rolfsen, R. 2013. Permian-Holocene tectonostratigraphic evolution of the Mandal High, Central Graben, North Sea. AAPG Bulletin, 97, 923-957. DOI: $10.1306 / 12031212093$

Sears, R.A., Harbury, A.R., Protoy, A.J.G. \& Stewart, D.J. 1993. Structural styles from the Central Graben in the UK and Norway. In: Parker, J.R. (ed) Petroleum Geology: NorthWest Europe and Global Perspectives - Proceedings of the 4th Petroleum Geology Conference. Geological Society, London, Petroleum Geology Conference series, 4, 12311243. https://doi.org/10.1144/0041231

Skibeli, M., Barnes, K., Straume, T., Syvertsen, S.E. \& Shanmugam, G. 1995. A sequence stratigraphic study of Lower Cretaceous deposits in the northernmost North Sea. In: Steel, R.J. (ed) Sequence Stratigraphy on the Northwest European Margin. NPF Special Publication, 5, 389-400.

Statoil. 1991. Well completion report Amalie-1 and Amalie 1A. Statoil Efterforskning OG Produktion A/S, Copenhagen, Denmark.

Stewart, S.A. 2007. Salt tectonics in the North Sea Basin: a structural style template for seismic interpreters. In: Ries, A.C., Butler, R.W.H., \& Graham, R.H. (eds) Deformation of 
the Continental Crust: The Legacy of Mike Coward. Geological Society, London, Special Publications, 272, 361-396. DOI: 10.1144/GSL.SP.2007.272.01.19

Strass, I.F. 1979. Lithology. Well 7/3-1. NPD Paper, 20. http://www.npd.no/engelsk/cwi/pbl/NPD_papers/164_01_NPD_Paper_No.20_Lithology_ _Well_7_3_1.pdf

Surlyk, F., Dons, T., Clausen, C.K. \& Higham, J. 2003. Upper Cretaceous. In: Evans, D., Graham, C., Armour, A. \& Bathurst, P. (eds) The Millennium Atlas: Petroleum Geology of the Central and Northern North Sea. Geological Society, London, 213-233.

Thorsrud, A., Jensen, J.R. \& Rasmussen, B.L. 2002. Final Well Report - Well Svane$1 \& 1 \mathrm{~A}$.

UKDD (UK Discovery Digest). 2007. Triassic Reservoirs of the Central Graben. Canadian Discovery Ltd., 9, 181-189. http://ukdigest.canadiandiscovery.com/?q=node/35892

Underhill, J.R. \& Partington, M.A. 1993. Jurassic thermal doming and deflation in the North Sea: implications of the sequence stratigraphic evidence. In: Parker, J.R. (ed) Petroleum Geology: North-West Europe and Global Perspectives - Proceedings of the 4th Petroleum Geology Conference. Geological Society, London, Petroleum Geology Conference series, 4, 337-345. DOI: 10.1144/0040337

Van Wijhe, D.H., 1987. Structural evolution of inverted basins in the Dutch offshore. Tectonophysics, 137, 171-219. Doi: https://doi.org/10.1016/0040-1951(87)90320-9

Van Winden, M., de Jager, J., Jaarsma, B. \& Bourollec, R. This Volume. New insights in salt tectonics in the northern Dutch offshore: a framework for exploration. In: Kilhams, B., Kukla, P., Mazur, S., McKie, T., Mijnlieff, H. \& Van Ojik, K. (eds) Mesozoic resource potential of the Southern Permian Basin. Geological Society of London Special Publications.

Vejbæk, O.V, Andersen, C., Dusar, M., Herngreen, G.F.W., Krabbe, H., Leszczyński, Lott, G.K., Mutterlose, J. \& Van Der Molen, A.S. 2010. Cretaceous. In: Doornenbal, J.C. and Stevenson, A.G. (eds) Petroleum Geological Atlas of the Southern Permian Basin Area. EAGE Publications b.v., Houten, 194-209.

Veeken, P. \& Rauch-Davies, M. 2006. AVO attribute analysis and seismic reservoir characterisation. First Break, 2, 7-18.

DOI: $10.3997 / 1365-2397.2006004$

Verolles, F. 1982. Geological completion report. Well 3/7-3. Elf Aquitaine Norge A/S Exploration Division. 311D/82/79-R. http://www.npd.no/engelsk/cwi/pbl/wellbore_documents/293_03_3_7_3_Completion_Rep ort.pdf 

Wiese, F., Wilmsen, M., Niebuhr, B., Reich, M., Funk, H., Michalík, Jagt, J.W.M., Felder, P.J. \& Schulp, A. 2008. Cretaceous. In: McCann, T. (ed) Geology of Central Europe. Geological Society, London, 923-998.

Vollset, J. \& Doré, A.G. 1984. A revised Triassic and Jurassic nomenclature for the Norwegian North Sea. NPD Bulletin, 3. http://www.npd.no/Global/Norsk/3-Publikasjoner/NPD-Bulletin/Bulletinenr3.pdf

Walker, J.D., Geissman, J.W., Bowring, S.A. \& Babcock, L.E. 2012. GSA Geologic Time Scale v. 4.0. Geological Society of America. https://www.geosociety.org/documents/gsa/timescale/timescl.pdf 264. geology of the Dutch Central North Sea Graben. Geologische Rundschau, 78 (1), 319336. doi:10.1007/BF01988367

Zanella, E., Coward, M.P., \& McGrandle, A. 2003. Structural Framework. In: Evans, D., Graham, C., Armour, A. \& Bathurst, P. (eds) The Millennium Atlas: Petroleum Geology of the Central and Northern North Sea. Geological Society, London, 44-60. 
1216 Table 1. List of sources for well data

\begin{tabular}{|c|c|c|}
\hline Type of data & Well & Datasource \\
\hline \multirow{3}{*}{$\begin{array}{l}\text { Lithostratigraphic tops } \\
\text { for seismic } \\
\text { interpretation }\end{array}$} & Norway & NPD 2017, Shell database \\
\hline & UK & Shell database \\
\hline & Denmark & Shell database \\
\hline \multirow{5}{*}{$\begin{array}{l}\text { Well shown in well } \\
\text { panel Fig. } 6\end{array}$} & UK 30/11b-1, UK 29/5a-5 & Milton-Worssell et al. 2006 \\
\hline & NO $2 / 1-8$ & Fjellanger 1986; NPD 2013 \\
\hline & NO $2 / 7-15$ & $\begin{array}{l}\text { Phillips 1981; Isaksen \& Tonstad } \\
1989\end{array}$ \\
\hline & NO $3 / 7-3$ & $\begin{array}{l}\text { Verolles 1982; Boirie \& Jeannou } \\
\text { 1984; NPD } 2017\end{array}$ \\
\hline & Amalie-1 & Statoil 1991 \\
\hline \multirow{12}{*}{$\begin{array}{l}\text { Other well data } \\
\text { described in text and } \\
\text { other images }\end{array}$} & Norway & NPD 2017 \\
\hline & NO $7 / 3-1$ & NPD 1979a; Strass 1979 \\
\hline & NO $17 / 10-1$ & NPD 1979b; Olsen 1979 \\
\hline & NO $17 / 11-1$ & A/S Norske Shell 1968 \\
\hline & NO $17 / 11-2$ & Provan 1976 \\
\hline & UKCG & Milton-Worssell et al. 2006 \\
\hline & Denmark (general) & Shell database \\
\hline & Sten-1 & Kern et al. 1983 \\
\hline & Tabita-1 & Bonde et al. 1994 \\
\hline & Iris-1 & Britoil 1985; Bonde et al. 1994 \\
\hline & Svane & Thorsrud et al. 2002 \\
\hline & West Lulu-4 & Mærsk 1987 \\
\hline $\begin{array}{l}\text { BCU and Top Lower } \\
\text { Cretaceous subcrop } \\
\text { data }\end{array}$ & e.g. NO 7/11-8, NO 3/7-1 & NPD 2017; Shell database \\
\hline
\end{tabular}




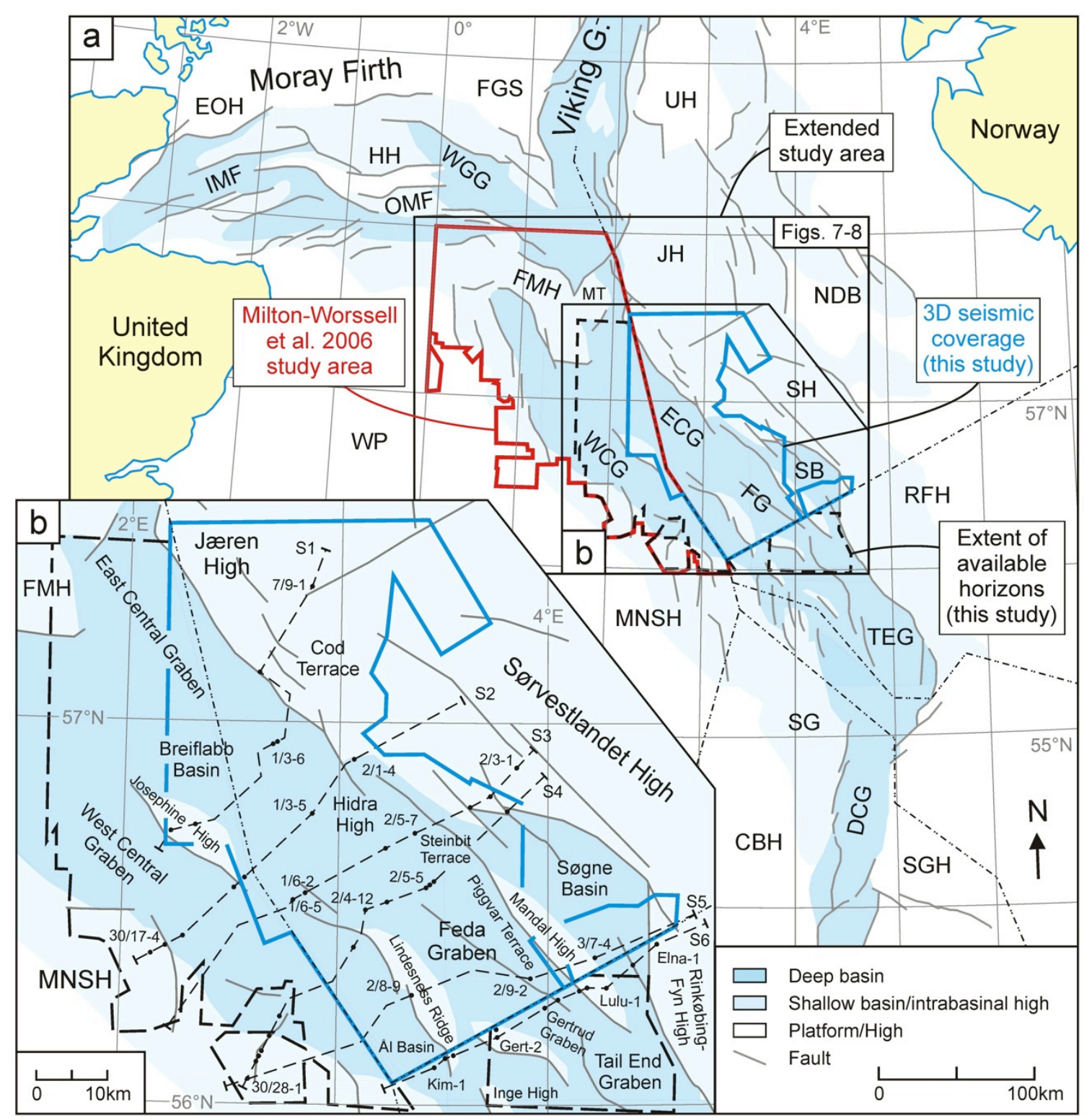

1221 Fig. 1. (a) Structural map of the Late Jurassic Central Graben depicting the study area 1222 (Norwegian Central Graben area and parts of the UK Central Graben) and the adjacent UK Central Graben study area of Milton-Worssell et al. (2006), that in combination define the extended study area. (b) Detailed map of the study area, indicating seismic coverage (blue) and the extent of available seismic depth maps (thick dotted outline). Dotted lines indicate interpreted seismic sections S1-S6 (Fig. 5). CBH: Cleaver Bank High, DCG: Dutch Central Graben, EOH: East Orkney High, NDB: Norwegian-Danish Basin, ECG: East Central Graben, FG: Feda Graben, FGS: Fladen Ground Spur, FMH: Forties-Montrose High, HH: Halibut High, IMF: Inner Moray Firth, JH: Jæren High, MNSH: Mid North Sea High, MT: Marnock Terrace, OMF: Outer Moray Firth, RFH: Ringkøbing-Fyn High, SB: Søgne Basin, SH: Sørvestlandet High, SG: Step Graben, SGH: Schill Ground High, TEG: Tail End Graben, UH: Utsira High, WCG: West Central Graben, WGG: With Ground Graben, WP: Western Platform. Modified after Fraser et al. (2003), Milton-Worssell et al. (2006) and Pharaoh et al. 


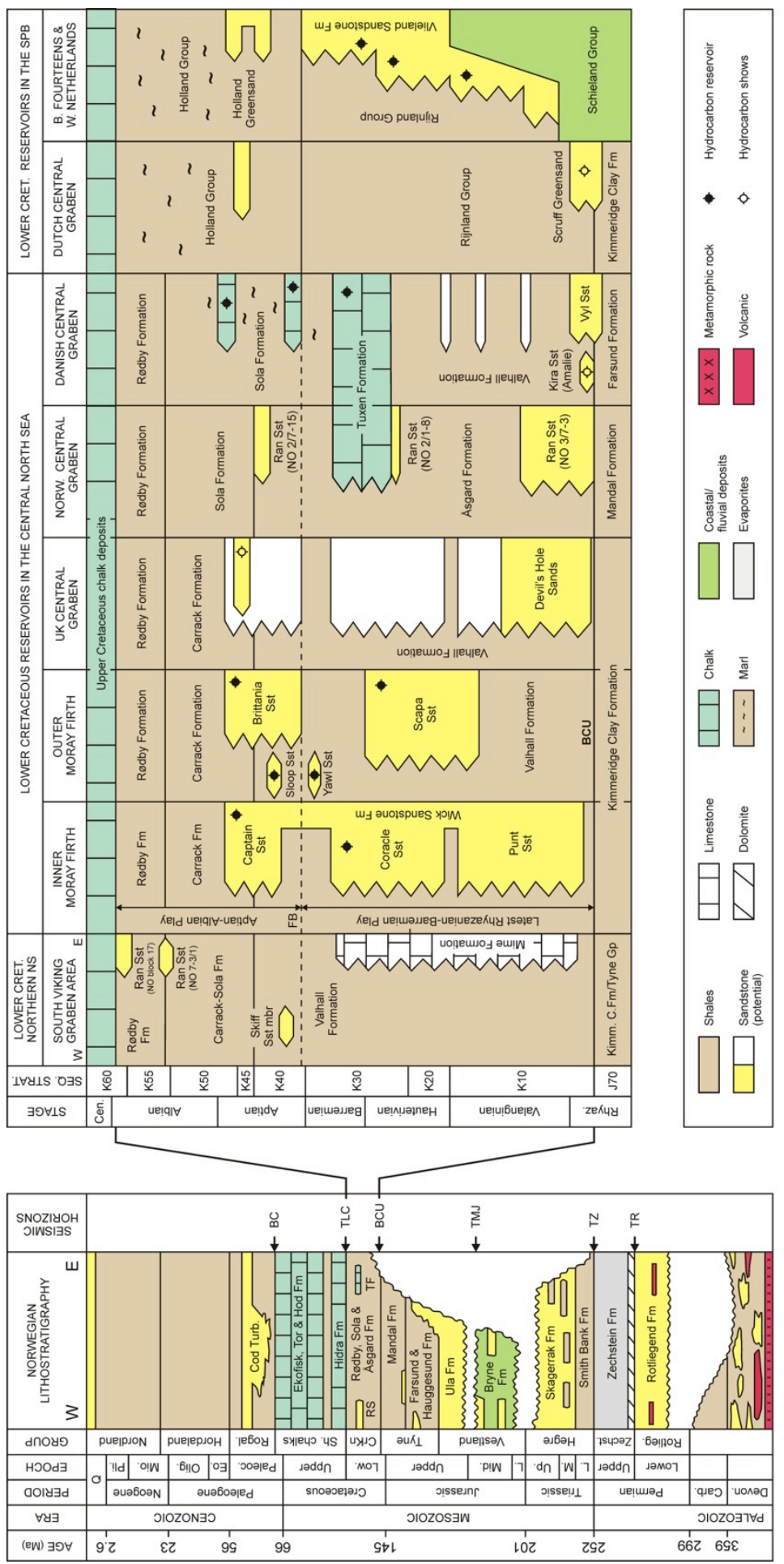

1236 Fig. 2. Norwegian lithostratigraphy for the study area (left) and overview of Lower 1237 Cretaceous reservoirs in the Central North Sea (right). CrKn: Cromer Knoll Group, FB:

1238 Fischerbank Schiefer, NS: North Sea, SPB: Southern Permian Basin. Seismic horizon 1239 abbreviations from top to bottom: BC: Base Cenozoic, TLC: Top Lower Cretaceous, BCU: 1240 Base Cretaceous Unconformity, TMJ: Top Middle Jurassic, TZ: Top Zechstein, TR: Top 1241 Rotliegend. Modified after Vollset \& Doré (1984), Van Wijhe (1987), Isaksen \& Tonstad 1242 (1989), Wong et al. (1989), Copestake et al. (2003), Milton-Worssell et al. (2006), De Jager 1243 \& Geluk (2007), Jakobsen et al. (2005); Herngreen \& Wong (2007), UKDD (2007), Wong 1244 (2007), NDD (2012). Geological timescale dates after Walker et al. (2012). 

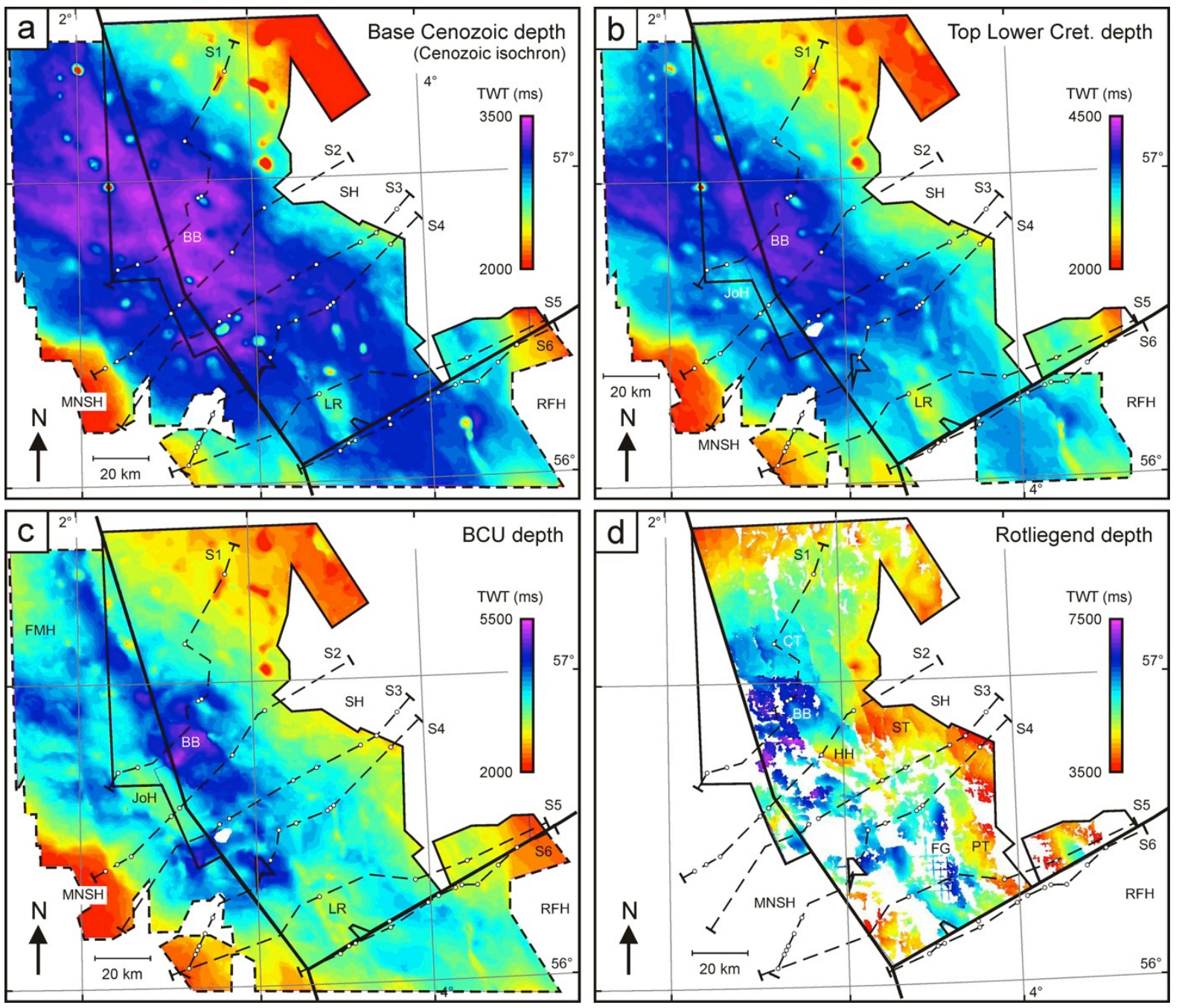

Fig. 3. Time depth maps of four regional horizons in the study area: (a) Base Cenozoic; (b) Top Lower Cretaceous; (c) Base Cretaceous Unconformity (BCU); (d) Top Rotliegend. Note that the Base Cenozoic time depth map (a) is also the Cenozoic isochron map and that the Top Rotliegend map is incomplete due to locally poor seismic quality. Dotted lines indicate the trace of interpreted transects S1-S6 and white dots indicate well locations along these transects (see Fig. 5). Solid outlines indicate the extent of the 3D seismic survey. Dashed outlines indicate the extent of the available previously interpreted seismic horizons in the UK and Denmark (see Fig. 1). BB: Breiflabb Basin, CT: Cod Terrace, FG: Feda Graben, HH: Hidra High, JoH: Josephine High; FMH: Forties-Montrose High; MNSH: Mid North Sea High, LR: Lindesness Ridge, PT: Pigvarr Terrace, RFH: Ringkøbing-Fyn High, SH: 

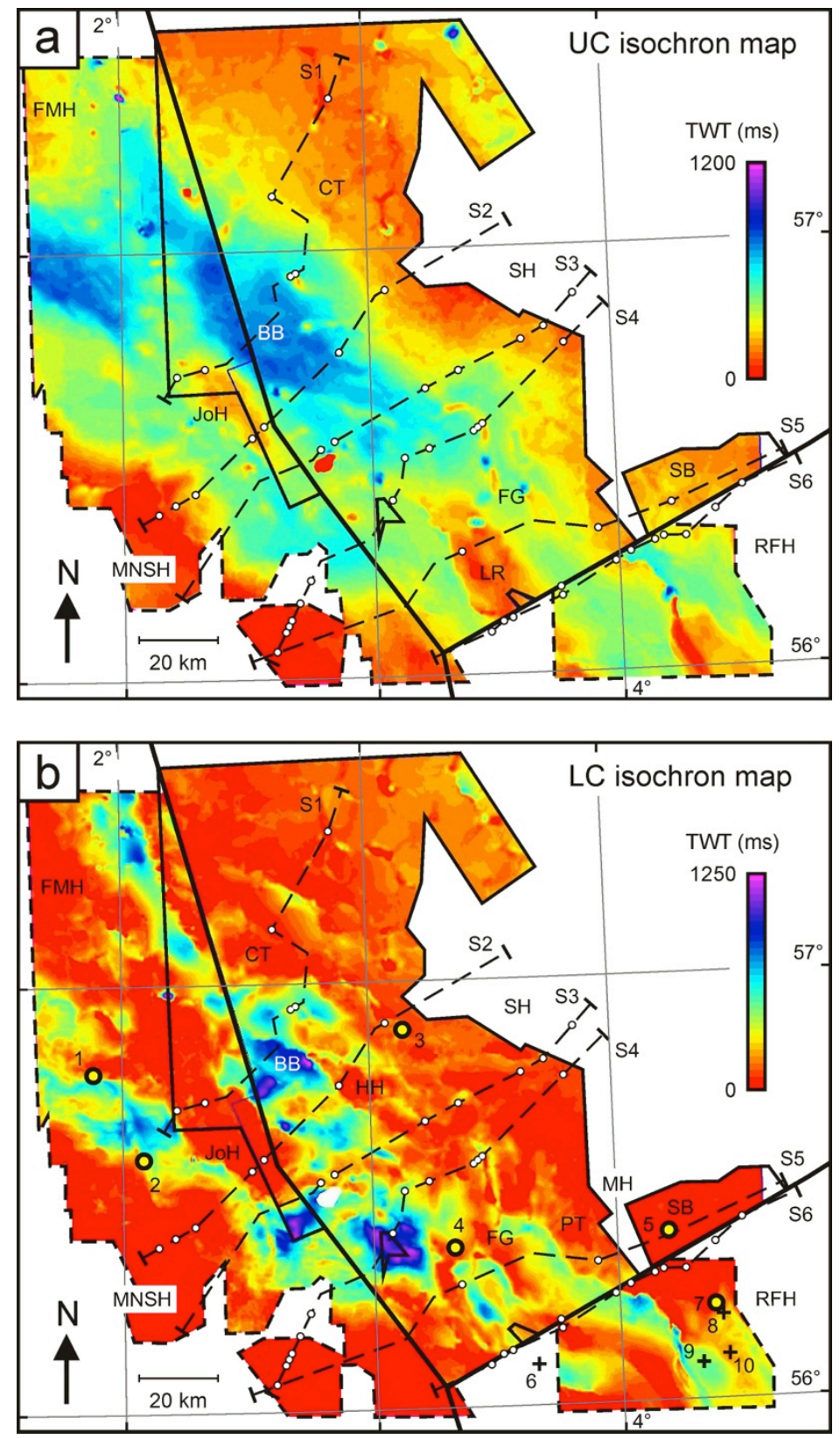

1261 Fig. 4. Isochron maps showing the location and geometry of depocenters in the study area in 1262 Two-way travel time. (a) UC: Upper Cretaceous isochron map; (b) LC: Lower Cretaceous 1263 (Cromer Knoll Group). Dotted lines indicate the trace of interpreted transects S1-S6 and 1264 wells along these transects (see Fig. 5). Solid outlines indicate the extent of the 3D seismic survey. Dashed outlines indicate the extent of the available previously interpreted seismic horizons in the UK and Denmark (see Fig. 1). The larger yellow dots indicate $>3 \mathrm{~m}$ sand occurences in wells within the study area, whereas crosses indicate sandstone traces $(<3 \mathrm{~m}$ thickness). Wells: (1) UK 29/5a-5, (2) UK 30.11b-1, (3) NO 2/1-8, (4) NO 2/7-15, (5) NO 3/7-3, (6) Sten-1, (7) Amalie-1, (8) Tabita-1, (9) Iris-1, (10) Svane-1. BB: Breiflabb Basin, CT: Cod Terrace, FG: Feda Graben, FMH: Forties-Montrose High, HH: Hidra High, JoH: Josephine High, MH: Mandal High, MNSH: Mid North Sea High, LR: Lindesness Ridge, PT: Pigvarr Terrace, RFH: Ringkøbing-Fyn High, SB: Søgne Basin, SH: Sørvestlandet High. 

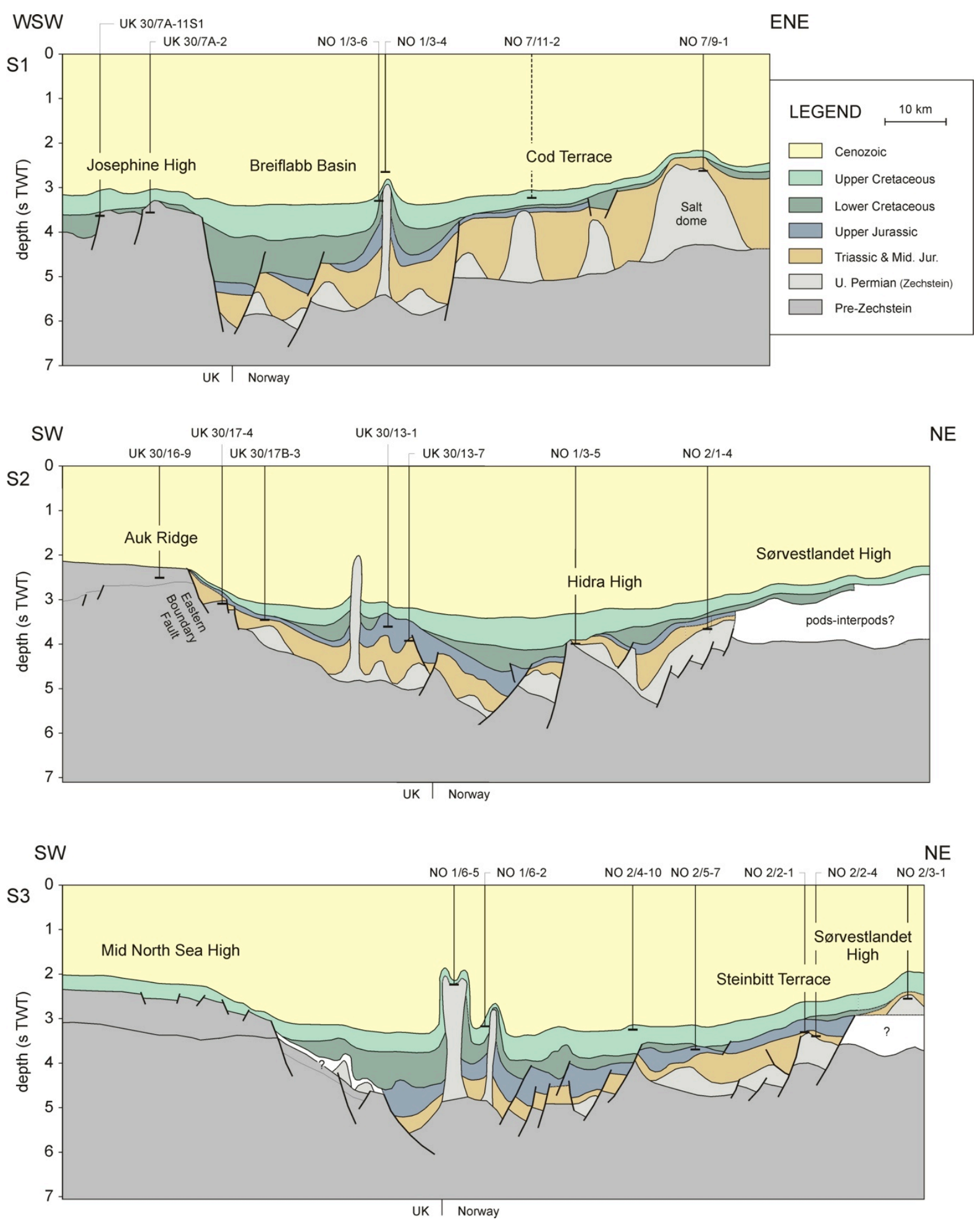

1275 Fig 5. Interpreted seismic sections S1-S3. UK: United Kingdom. For section locations see 1276 Fig. 1b. Reference datum is mean sea level. 

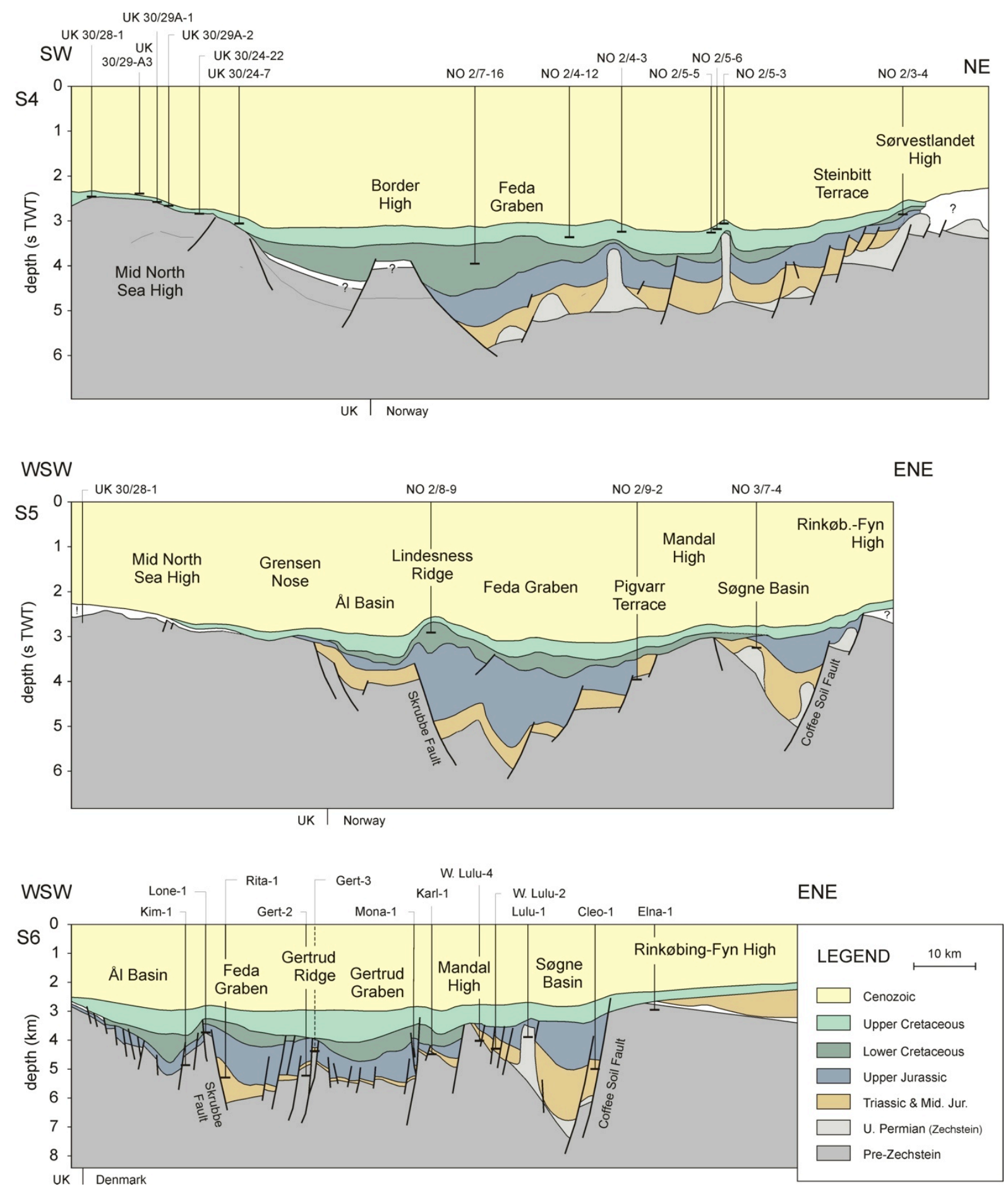

1278 Fig 5. (continued) Interpreted seismic sections S4-S6. UK: United Kingdom. For section 1279 locations see Fig. 1b. Section S6 modified after Møller \& Rasmussen (2003). Reference 1280 datum is mean sea level. 


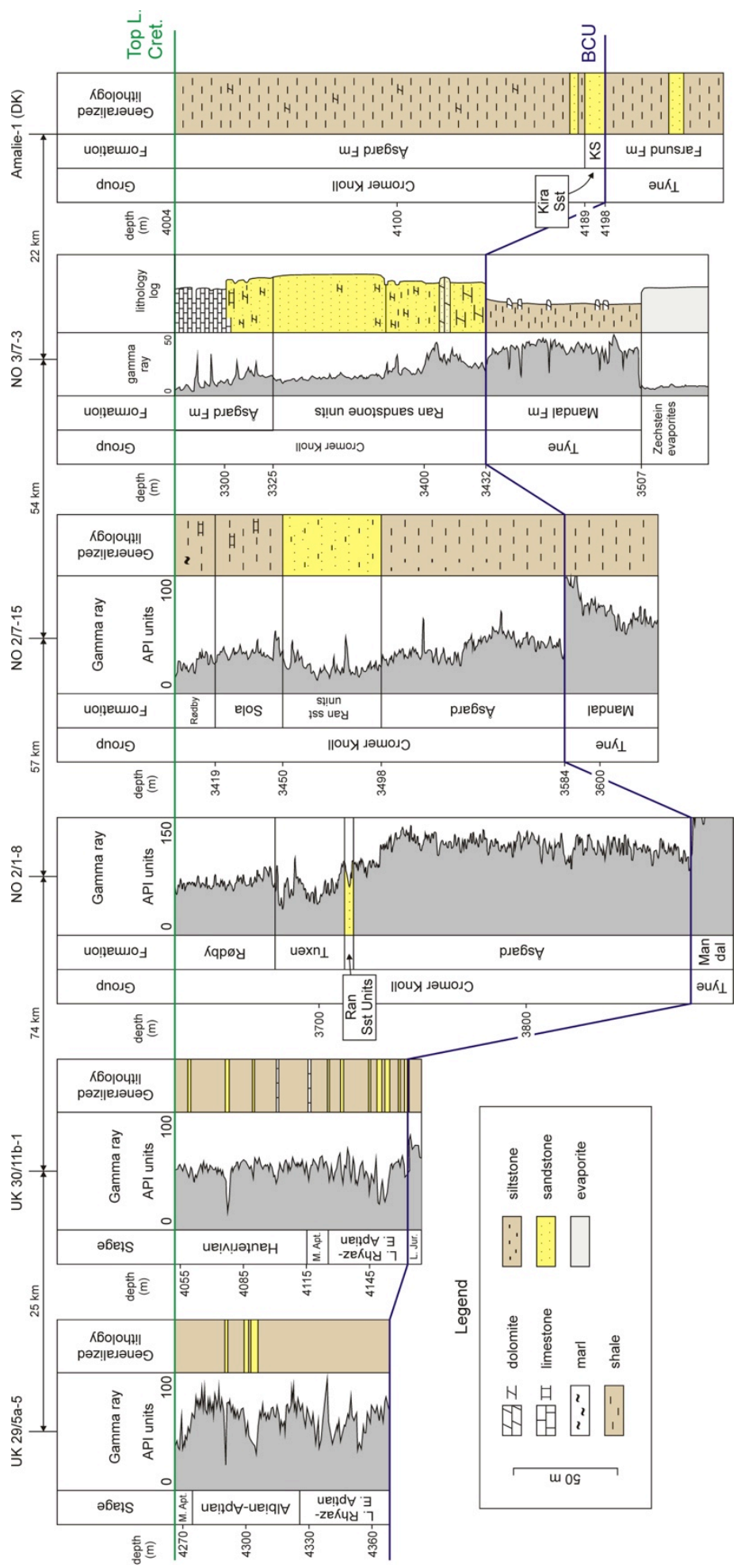

1285 Fig. 6. Well data from wells UK 30/11b-1 and UK 29/5a-5 (modified after Milton-Worssell et al. 2006), NO 2/1-8 (modified after NPD 2013), NO 2/7-15 (modified after Isaksen \& 1287 Tonstad 1989), NO 3/7-3 (modified after Boirie \& Jeannou 1984) and Amalie-1 (DK, modified after Statoil 1991), all containing Lower Cretaceous (Ran/Kira) Sandstone units and hung off Top Lower Cretaceous level (Fig. 2). No lithology data are available for well NO 2/1-8. No Gamma Ray data available for well Amalie-1. Locations shown in Fig. 4b. 


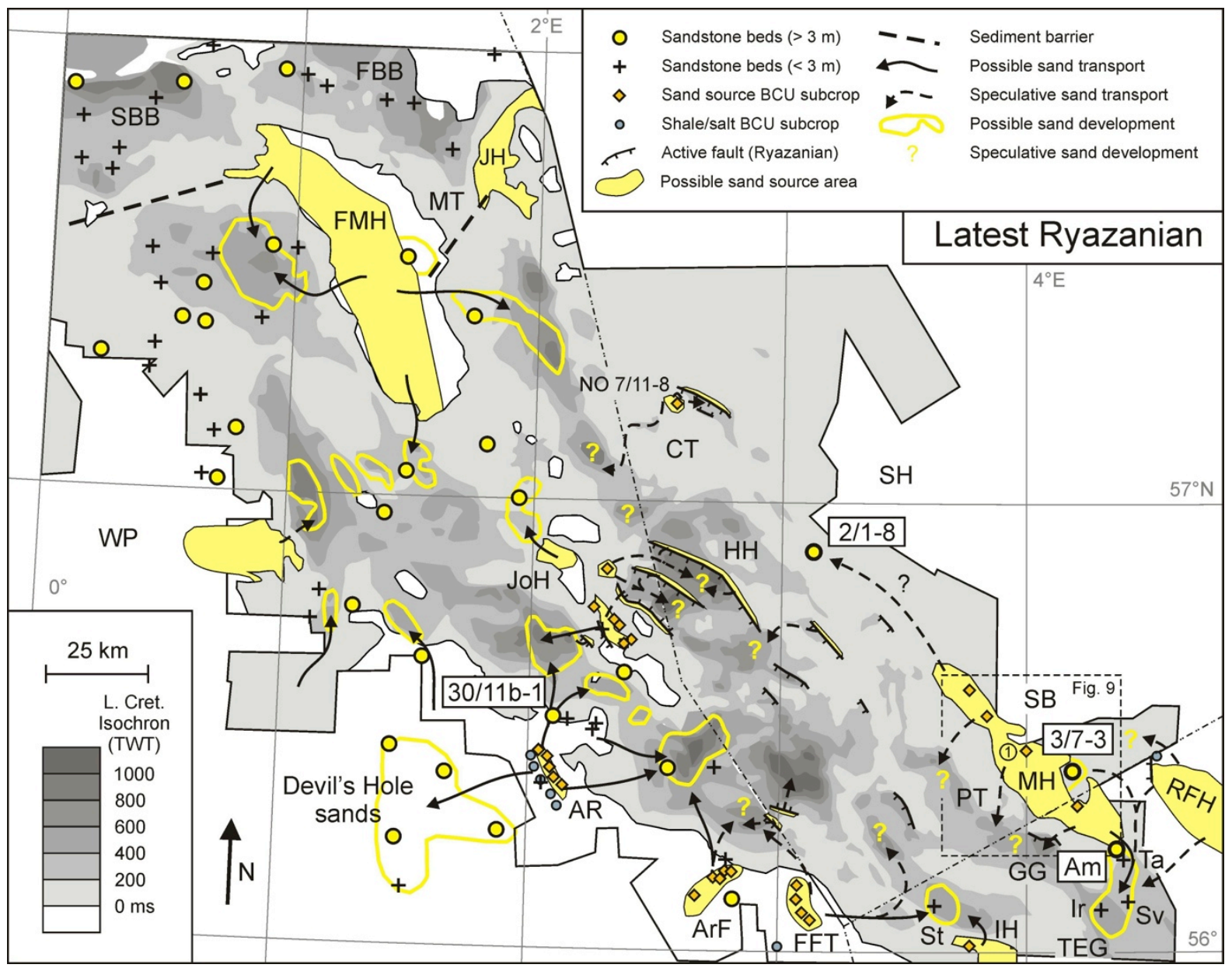

1294 Fig. 7. Interpretation of reservoir potential in the extended study area for the Latest Ryazanian (BCU-level). Well data, possible sand source areas, Ryazanian fault activity, possible sediment transport fairways and areas of possible sandstone development are projected on top of the Lower Cretaceous isochron map. Well identifiers are Ir: Iris-1, St: Sten-1, Sv: Svane-1, Ta: Tabita-1, (1): well NO 3/7-1. AR: Auk Ridge, ArF: Argyl Field, CT: Cod Terrace, FBB: Fisher Bank Basin, FFT: Flora-Fife Trend, FMH: Forties-Montrose High, GG: Gertrud Graben, HH: Hidra High, IH: Inge High, JH: Jæren High, JoH: Josephine High, MH: Mandal High, MT: Marnock Terrace, PT: Piggvar Terrace, RFH: Ringkøbing-Fyn High, SB: Søgne Basin, SBB: South Buchan Basin, SH: Sørvestlandet High, TEG: Tail End Graben, WP: Western Platform. Modified after Japsen et al. (2003), Milton-Worssell et al. (2006) and Rossland et al. (2013). 


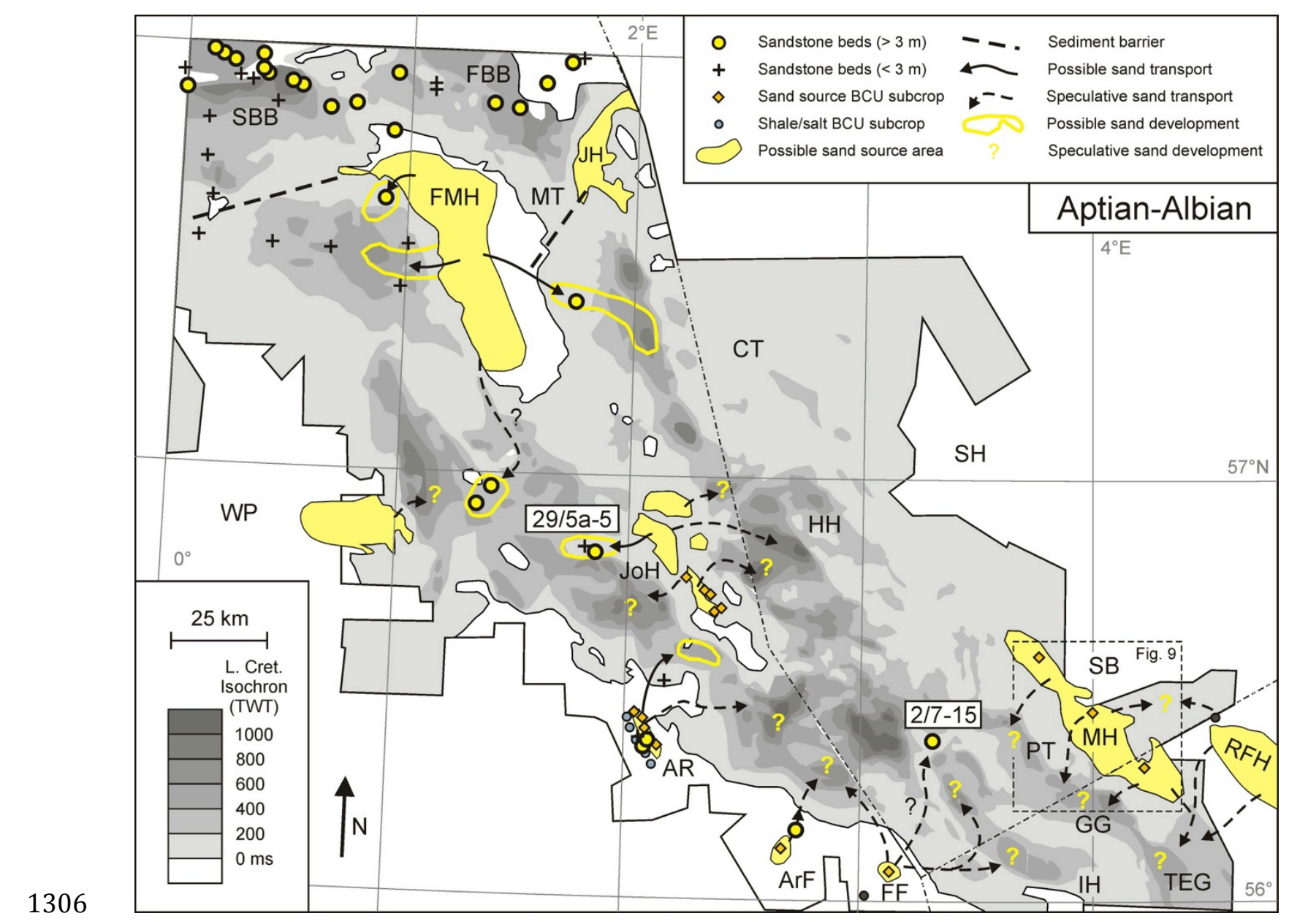

1307 Fig. 8. Interpretation of reservoir potential throughout the extended study area for the Aptian1308 Albian (near-Top Lower Cretaceous level). Well data, possible sand source areas, interpreted 1309 possible sediment transport fairways and areas of possible sandstone development are 1310 projected on top of the Lower Cretaceous isochron map. AR: Auk Ridge, ArF: Argyl Field 1311 CT: Cod Terrace, FBB: Fisher Bank Basin, FF: Flora Field, FMH: Forties-Montrose High, 1312 GG: Gertrud Graben; HH: Hidra High, IH: Inge High, JH: Jæren High, JoH: Josephine High, 1313 MH: Mandal High, MT: Marnock Terrace, PT: Piggvar Terrace; RFH: Ringkøbing-Fyn 1314 High, SB: Søgne Basin, SBB: South Buchan Basin, SH: Sørvestlandet High, TEG: Tail End 1315 Graben, WP: Western Platform. Modified after Japsen et al. (2003), Milton-Worssell et al. 1316 (2006) and Rossland et al. (2013). 


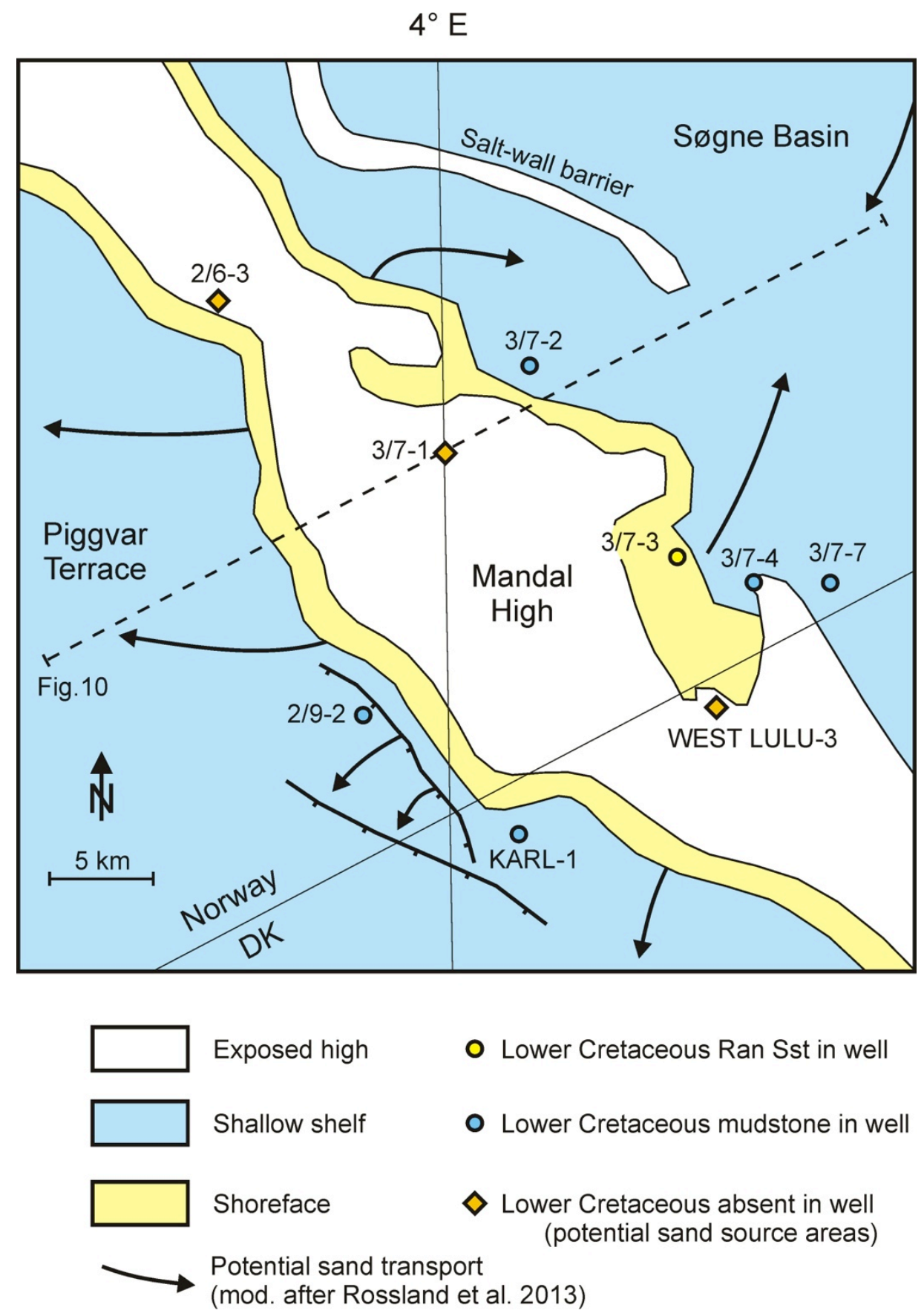

1319 Fig. 9. Proposed Early Cretaceous paleogeographic situation around the Mandal High area. Image modified after Rossland et al. (2013). 


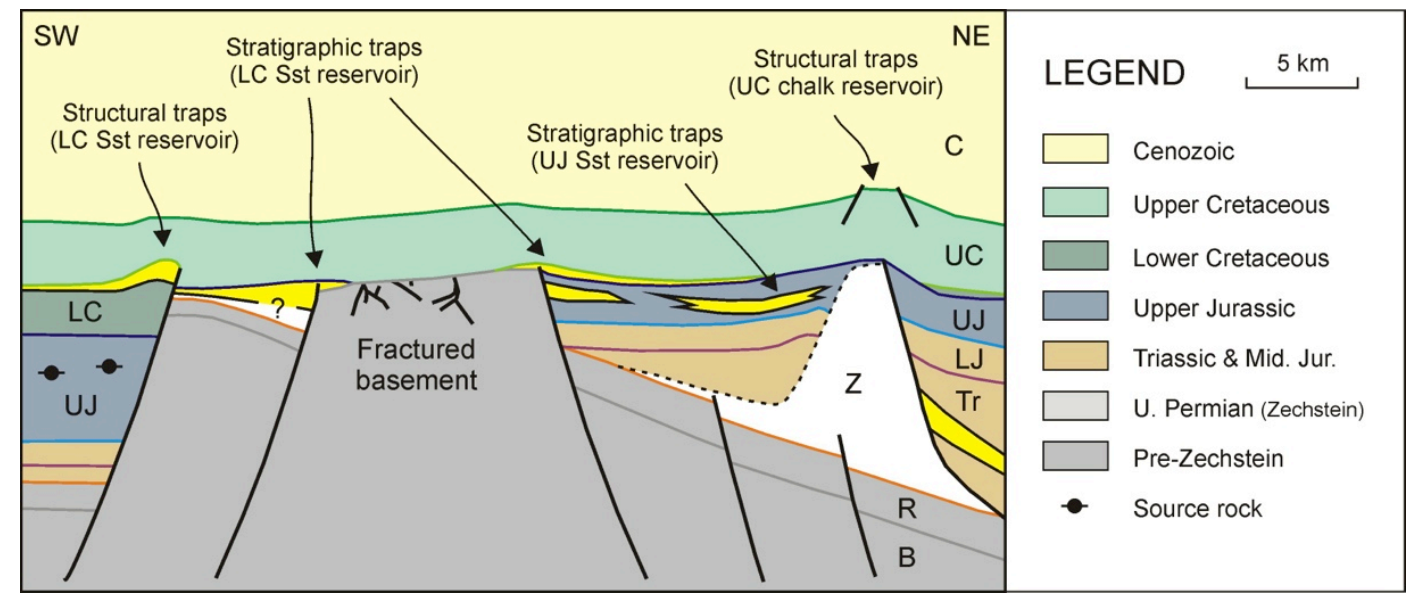

1323 Fig. 10. Idealised cross section proposing the main potential reservoirs and traps in the 1324 Mandal High-Søgne Basin area. C: Cenozoic, UC: Upper Cretaceous, LC: Lower Cretaceous, 1325 UJ: Upper Jurassic. LJ: Lower Jurassic, Tr: Triassic, Z: Zechstein (evaporites), R: 1326 Rotliegend, B: Pre-Permian sediments and/or (metamorphic) Basement. Image modified after 1327 Rossland et al. (2013). 


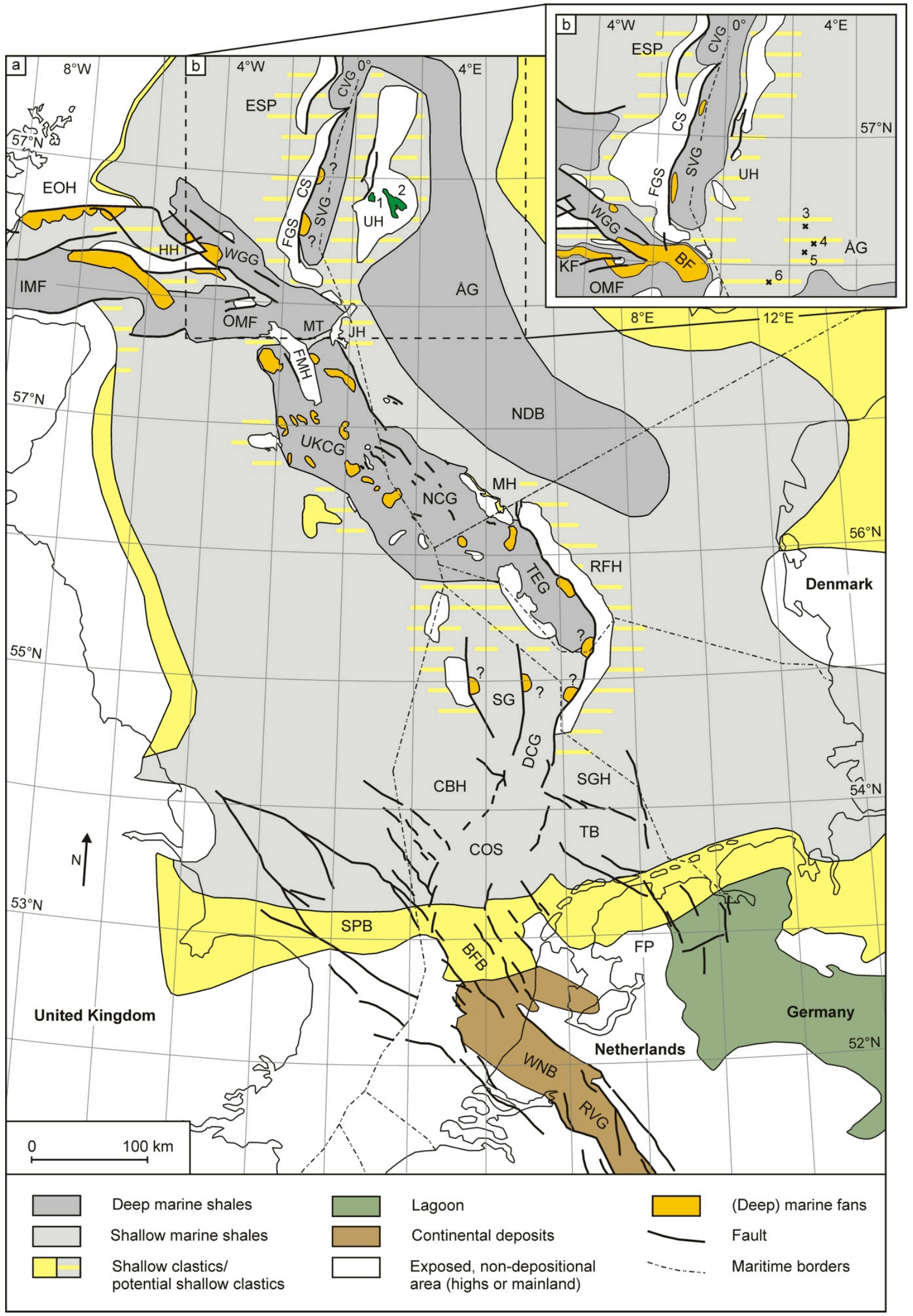


1331 Fig. 11. (a) Gross depositional environment overview of the Central and Southern North Sea in Ryazanian times (K10). (b) Gross depositional environment of the South Viking Graben area in Aptian times (K40-50), corresponding to the Aptian-Albian reservoir interval. Lower Cretaceous sand presence: (1) Edvard Grieg field, (2) Johan Sverdrup field, (3) well NO 7/10-1, (4) well NO 7/11/-1, (5) well NO 7/11-2, (6) well NO 7/3-1, ÅG: Åsta Graben, BF: Britannia Field, BFB: Broad Fourteens Basin, CBH: Cleaver Bank High, COS: Central Offshore Saddle, CS: Crawford Spur, CVG: Central Viking Graben, DCG: Dutch Central Graben, EOH: East Orkney High, ESP: East Shetland Platform, FP: Friesland Platform, HH: Halibut High, IMF: Inner Moray Firth, JH: Jæren High, FMH: Forties-Montrose High, KF: Kopervik Fairway, MH: Mandal High, MT: Marnock Terrace, NCG: Norwegian Central Graben, NDB: Norwegian-Danish Basin, OMF: Outer Moray Firth, RFH: Ringkøbing-Fyn High, RVG: Roer Valley Graben, SG: Step Graben, SGH: Schill Grund High, SPB: Sole Pit Basin, TB: Terschelling Basin, TEG: Tail End Graben (Danish Central Graben), UH: Utsira High, UKCG: UK Central Graben, WGG: Witch Ground Graben, WNB: West Netherlands Basin. Modified after Copestake et al. (2003), NPD (2017) for the South Viking Graben area, after Milton-Worsell et al. (2006), Copestake et al. (2003), Rossland et al. (2013) for the UKCG and NCG, after Vejbæk et al. (2010), after Pharaoh et al. (2010) for the Danish, German and (parts of) the Dutch Central Graben, and after Jeremiah et al. (2010) for the Southern North Sea. 